\title{
BHLHB2 Controls Bdnf Promoter 4 Activity and Neuronal Excitability
}

\author{
Xueying Jiang, ${ }^{1}$ Feng Tian, ${ }^{1}$ Yang Du, ${ }^{3}$ Neal G. Copeland, ${ }^{3}$ Nancy A. Jenkins, ${ }^{3}$ Lino Tessarollo, ${ }^{3}$ Xuan Wu, ${ }^{4}$ Hongna Pan, ${ }^{4}$ \\ Xian-Zhang Hu, ${ }^{1}$ Ke Xu, ${ }^{2}$ Heather Kenney, ${ }^{1}$ Sean E. Egan, ${ }^{5,6}$ Helen Turley, ${ }^{7}$ Adrian L. Harris, ${ }^{7}$ Ann M. Marini, ${ }^{4}$ and \\ Robert H. Lipsky ${ }^{1}$ \\ ${ }^{1}$ Section on Molecular Genetics, ${ }^{2}$ Section on Human Genetics, Laboratory of Neurogenetics, National Institute on Alcohol Abuse and Alcoholism, National \\ Institutes of Health, Bethesda, Maryland 20892, ${ }^{3}$ Mouse Cancer Genetics Program, National Cancer Institute, Center for Cancer Research, Frederick, \\ Maryland 21702, ${ }^{4}$ Department of Neurology, Uniformed Services University of the Health Sciences, Bethesda, Maryland 20814, ${ }^{5}$ Program in Developmental \\ and Stem Cell Biology, The Hospital for Sick Children, University of Toronto, Toronto, Ontario, Canada M5G 1X8, ${ }^{6}$ Department of Molecular and Medical \\ Genetics, University of Toronto, Toronto, Ontario, Canada M5S 1A8, and 7Laboratory of Molecular Oncology, Weatherall Institute of Molecular Medicine, \\ University of Oxford, John Radcliffe Hospital, Oxford OX3 9DS, United Kingdom
}

Brain-derived neurotrophic factor (BDNF), via activation of TrkB receptors, mediates vital physiological functions in the brain, ranging from neuronal survival to synaptic plasticity, and has been implicated in the pathophysiology of neurodegenerative disorders. Although transcriptional regulation of the BDNF gene $(B d n f)$ has been extensively studied, much remains to be understood. We discovered a sequence within Bdnf promoter 4 that binds the basic helix-loop-helix protein BHLHB2 and is a target for BHLHB2-mediated transcriptional repression. NMDA receptor activation de-repressed promoter 4-mediated transcription and correlated with reduced occupancy of the promoter by BHLHB2 in cultured hippocampal neurons. Bhlhb2 gene - I- mice showed increased hippocampal exon 4-specific Bdnf mRNA levels compared with $+/+$ littermates under basal and activity-dependent conditions. Bhlhb2 knock-out mice also showed increased status epilepticus susceptibility, suggesting that BHLHB2 alters neuronal excitability. Together, these results support a role for BHLHB2 as a new modulator of $B d n f$ transcription and neuronal excitability.

Key words: brain-derived neurotrophic factor; BDNF; neuronal excitability; BHLHB2; DEC1/Sharp2/Stra13; transcription

\section{Introduction}

Neurotrophins are a family of trophic factors related by primary amino acid sequence homology. One member of this family is brain-derived neurotrophic factor (BDNF). Among its primary functions, BDNF modulates the strength of existing synaptic connections and acts in forming new synaptic contacts (Thoenen, 1995; Katz and Shatz, 1996; Lu and Figurov, 1997; Chao, 2003). BDNF is also critical in CNS development, neuronal survival, and rapid signaling via its cognate receptor, TrkB (Ghosh et al., 1994; Schwartz et al., 1997; Marini et al., 1998; Kafitz et al., 1999; Vajda, 2002). BDNF is synthesized principally by neurons and is highly expressed throughout the brain, including the cortex and hippocampus (Ernfors et al., 1990; Phillips et al., 1990; Yan et al., 1997), two regions involved in plasticity.

Two transcription factors known to play important roles in neuronal and synaptic plasticity are cAMP response elementbinding protein (CREB) and nuclear factor $-\kappa \mathrm{B}(\mathrm{NF}-\kappa \mathrm{B})$. Both CREB (Frank and Greenberg, 1994; Yin et al., 1994; Wood et al.,

Received May 17, 2007; revised Nov. 15, 2007; accepted Dec. 10, 2007.

This work was supported by National Institutes of Health Intramural Grant NIAAA Z01-AA00325 (R.H.L.) and Extramural Grant F-192EG-C1 from the Defense Brain and Spinal Cord Injury Program (A.M.M.).

Correspondence should be addressed to Robert H. Lipsky, 5625 Fishers Lane, Room 3S32, MSC 9412, Bethesda, MD 20892-9412. E-mail: rlipsky@mail.nih.gov.

DOI:10.1523/JNEUROSCI.2262-07.2008

Copyright $\odot 2008$ Society for Neuroscience $\quad$ 0270-6474/08/281118-13\$15.00/0
$2005)$ and NF- $\kappa$ B (Meberg et al., 1996; Freudenthal and Romano, 2000; Mattson et al., 2000; Meffert et al., 2003; Freudenthal et al., 2004) have been implicated in synaptic plasticity and behavior in organisms ranging from Drosophila to crabs to mammals. Both transcription factors bind to promoter 4 of the $B d n f$ gene to initiate activity-dependent transcription. However, other potential cis-acting elements are present in this conserved and functionally important region. One such site is a class B E-box that sits between the CREB and NF- $\kappa$ B binding sites, whose effect on Bdnf transcription was a focus of the present study.

BHLHB2 is a member of the basic helix-loop-helix (bHLH) superfamily of transcription factors. BHLHB2 binds to class B E-box sites on DNA either as heterodimers or homodimers and regulates numerous biological processes. BHLHB2 (also known as Sharp2, Stra13, and DEC1), is highly expressed in the rat brain (Rossner et al., 1997). Onset of BHLHB2 gene (designated Bhlhb2 in mouse) transcription begins late in rat brain development (postnatal day 5) and increases through postnatal development in which it reaches its highest level in the adult brain (Rossner et al., 1997). BHLHB2 is expressed by neurons in the cortex and hippocampus and has immediate-early gene characteristics. The gene is regulated by NGF, another member of the neurotrophin family, and glutamate receptors (Rossner et al., 1997), suggesting that BHLHB2 is involved in plastic responses in the brain.

We found that BHLHB2 binds to a class B E-box that lies 
between known cAMP response element (CRE) and NF- $\kappa$ B binding sites within promoter 4 . NMDA receptor activation reduced endogenous BHLHB2 occupancy of promoter 4 while enhancing recruitment of activated CREB and NF- $\kappa \mathrm{B}$ in hippocampal neurons. Basal and activity-dependent exon 4 -specific $B d n f$ transcription was de-repressed in Bhlhb2 knock-out (KO) mice. In addition, Bhlhb2 KO mice exhibited increased susceptibility to status epilepticus. Together, these findings suggest that the $B d n f$ gene is a critical target of BHLHB2 and that BHLHB2 may mediate its effect on synaptic function and neuronal activity as a transcriptional repressor.

\section{Materials and Methods}

Generation of Bhlhb2 KO mice. The conditional gene-targeting vector was constructed using a novel recombineering approach described previously (Liu et al., 2003) and is shown schematically in supplemental Figure 1 (available at www.jneurosci.org as supplemental material). A 129 bacterial artificial chromosome (BAC) library (CT7; Invitrogen, Carlsbad, CA) was screened with a Bhlhb2 genomic probe to identify a BAC clone containing the Bhlhb2 genomic locus (clone no. 532I15). A $14.4 \mathrm{~kb}$ BglII-SpeI restriction fragment from clone 532I15 was then isolated and ligated into a ES cell targeting vector PL253 (Liu et al., 2003) using BamHI and SpeI sites. A single lox2272 and a lox2272 plus Frtflanked neo cassette were targeted to the resulting construct in two steps in EL350 cells through recombineering as previously described (Liu et al., 2003). First, to insert the single 5' lox2272 site, a targeting cassette containing Pgk-em7-neo flanked by homology arms to regions 5' of Bhlhb2 exon 1 was constructed in YD400, a plasmid identical to PL400 except containing two lox2272 sites replacing two wild-type (WT) loxp sites. The homology arms are PCR amplified using the following primers: $5^{\prime}$-arm sense, 5' -CGCGGCGGCCGCGGAGAGGCTTGCAAGTGAGC-3'; 5' arm antisense, $5^{\prime}$-CGCGACTAGTCCAGGCGCAGCCTGCGGGTG-3'; 3'-arm sense, 5' -CGCGGAATTCGACCTGAGCTCCCGGGAGAG-3'; $3^{\prime}$-arm antisense, 5' -CGCGAAGCTTAACCGGTGCGCAGCTGA-GG$3^{\prime}$. The homology arms were sequence verified, restriction digested $\left(5^{\prime}-\right.$ arm with NotI plus SpeI, and $3^{\prime}$-arm with EcoRI plus HindIII), and cloned into YD400 via four-way ligation. The targeting cassette was released by NotI/HindIII double digest and targeted through coelectroporation into heat shock-induced EL350 cells as described previously (Liu et al., 2003). The Pgk-em7-neo sequence was then removed by electroporation into arabinose-induced Cre-expressing EL350 cells, leaving behind a single lox2272 and a SpeI site for genotyping purpose. To insert the second lox2272 site $3^{\prime}$ of Bhlhb2 exon 4, a targeting cassette containing frt-Pgk-Em7-neo-frt-lox2272 was constructed in YD451, a plasmid otherwise identical to PL451 except having one lox2272 site instead of the original loxp site. Homology arms were amplified using the following primers: 5' -arm sense, 5' -CGCGGGATCCTTCATGGGCGAACAGAACAC- $3^{\prime} ; 5^{\prime}$-arm antisense, $5^{\prime}$-CGCGCTCGAGTGGGGTACATATTAGGATTC-3'; $3^{\prime}$-arm sense, 5'-CGCGGAATTCATAGGCGTTCTTCAGTCCTG-3'; 3'-arm antisense, 5'-CGCGAAGCTTTGAGGCTGGCAGGTTACTTC-3'. The targeting cassette was released by BamHI/ HindIII double digest and targeted similarly as described above. All PCRs were performed using BAC 532I15 DNA as template and conditions were as follows: $94^{\circ} \mathrm{C}$ for $15 \mathrm{~s}, 60^{\circ} \mathrm{C}$ for $30 \mathrm{~s}$, and $72^{\circ} \mathrm{C}$ for $60 \mathrm{~s}$ for $30 \mathrm{cycles}$. The conditional targeting vector was then linearized by NotI digestion and electroporated into 129-derived CJ7 embryonic stem (ES) cells, using standard procedures. G418 (180 $\mu \mathrm{g} / \mathrm{ml})$ and Ganciclovir $(2 \mu \mathrm{M})$ doubleresistant clones were analyzed by Southern blotting hybridization, using both $5^{\prime}$ and $3^{\prime}$ external probes (see supplemental material, available at www.jneurosci.org). These external probes were PCR amplified using the following primers: $5^{\prime}$ probe, sense, $5^{\prime}$-GCCATATGTGGCAAAACGTG3'; 5' probe, antisense, 5'-CAGATCTCTCCTCCTTCTCAG-3'; 3'probe, sense, 5'-GCATTTGGCTTGTCATGTGC-3'; $3^{\prime}$-probe, antisense, 5'-CACTTGGTAAGAGTGCTTGC-3'. Correctly targeted clones were then injected into $\mathrm{C} 57 \mathrm{BL} / 6$ blastocysts using standard procedures, and resulting chimeras were mated with $\mathrm{C} 57 \mathrm{BL} / 6$ females to obtain germline transmission of the targeted (neo) allele. The conditional knock-out (cko) allele was obtained by crossing Bhlhb2 neo mice to
$\beta$-actin-Flp transgenic mice. The null $(k o)$ allele was then obtained by crossing Bhlhb2 cko mice to $\beta$-actin-Cre transgenic mice. The ko allele eliminates coding exons 1 through 4 from Bhlhb2, which include the bHLH (DNA binding and dimerization) domains. The KO line was maintained by intercrossing Bhlhb2 $+/-$ heterozygous mice. The mice were kept on a mixed genetic background (129, C57BL/6, and CD1). These Bhlhb2 KO mice are viable and fertile with no apparent abnormality. When aged for a year, they did not develop obvious signs of autoimmune disease observed in a different Bhlhb2-deficient mouse line described previously (Sun et al., 2001). This discrepancy could be attributable to the genetic background difference between the two lines as the previous line is maintained on either pure 129 or 129 and C57BL/6 mixed background. A possible difference in housing condition for these animals may also play a role because environmental factors such as infections are known to play crucial roles in triggering autoimmune diseases. Mice were genotyped by a PCR-based method using ear punch DNA (supplemental Fig. 2, available at www.jneurosci.org as supplemental material). This method used two sets of primer pairs: the WT primer pair amplified a 727 bp product only from the intact $B h l h b 2$ gene, whereas the second set $(\mathrm{KO})$ produced a $555 \mathrm{bp}$ band representing the null allele. The primer sequences were as follows: WT sense, 5'-GCCCTGCAGAGCGGTTTACA-3', WT antisense, 5'-GCAGACATACTGGCTTGGTTTGGT-3'; KO sense, 5'-TGTGGAGATTTCACTGTG-

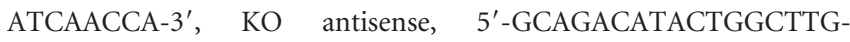
GTTTGGT-3'. PCR products were resolved on $10 \%$ polyacrylamide gels, and the bands were visualized by ethidium bromide staining. Bhlhb2 mutant mice and Bhlhb2 $+1+$ control littermates were selected at 5-6 months of age for subsequent analyses.

Kainic acid administration. Mice were injected intraperitoneally with kainic acid (KA) in PBS (10 mg/kg). Mice were monitored and the extent of seizure activity was observed. Seizure severity (determined by forelimb clonus, partial rearing, rearing and falling) was scored according to stages as described by Liu et al. (1999): stage 0, no abnormal behavior; stage 1, cessation of exploring, sniffing, and grooming with mice becoming motionless; stage 2, forelimb and/or tail extension with the appearance of a rigid posture; stage 3 , myoclonic jerks of the head and neck, with head bobbing, with brief twitching movement; stage 4 , forelimb clonus and partial rearing; stage 5, forelimb clonus, rearing and falling; stage 6, tonic-clonic movements with loss of posture and sometimes death. Time of seizure initiation (from KA injection to achieve seizure) did not differ between genotype groups. The investigator evaluating seizure stage and duration was blinded to genotype.

Cell culture. Primary rat neurons were prepared from hippocampi that were removed from brains at embryonic day 20. Tissue was dissociated by mild trypsinization and trituration as described previously (Cheng et al., 1995; Jiang et al., 2005b). Hippocampal cells were then plated onto poly-D-lysine-coated culture dishes. Hippocampal neurons were maintained under serum-free conditions throughout the cultivation period. One-fifth of the medium was removed and replaced with fresh medium every third day to replenish nutrients. All experimental treatments were performed on neurons on day in vitro (DIV) 7-8, which contained 9095\% neurons, except for experiments using the reporter gene constructs. Hippocampal neurons cultured in serum-free medium have been extensively characterized using neuronal and glial antibodies (Fu et al., 2002; Perry et al., 2003). For transfection experiments, NIH3T3 fibroblasts were propagated in DMEM supplemented with 10\% fetal bovine serum. In a separate experiment, NIH3T3 cells were grown in DMEM with $10 \%$ fetal bovine serum. When the cells reached confluence, the medium was switched to DMEM with $0.1 \%$ fetal bovine serum for $24 \mathrm{~h}$ to induce BHLHB2 expression (Sun and Taneja, 2000). Neurons used for transfection experiments were plated in 12- or 24-well plates and maintained for $3 \mathrm{~d}$ before transfection using Lipofectamine 2000, according to the manufacturer's procedure (Invitrogen). Decoy DNAs were transfected into hippocampal neurons using the method of Lipsky et al. (2001).

In vitro DNA binding activity determinations by gel shift. Nuclear extracts were prepared from cell lines or cultured rat hippocampal neurons using a nuclear extract kit (Active Motif, Carlsbad, CA). Hippocampal neurons were incubated with $50 \mu \mathrm{M}$ NMDA for 40 min before harvesting cells and preparing nuclear extracts. These neuronal nuclear extracts 
were used for determining NF- $\kappa$ B and CREB DNA binding activity (supplemental Figs. 3, 5, available at www.jneurosci.org as supplemental material). Preliminary protein blot experiments were used to determine the time point for gel shift experiments based on the time course of activation for CREB and inhibitory NF- $\kappa \mathrm{B}-\alpha(\mathrm{I}-\kappa \mathrm{B}-\alpha)$ by NMDA in hippocampal neurons (supplemental Fig. 4, available at www.jneurosci.org as supplemental material). Protein content was determined using a Bradford dyebinding assay (Bio-Rad Laboratories, Hercules, CA), and protein content was equalized by dilution. Nuclear extracts from primary rat hippocampal neurons and NIH3T3 cells were examined for DNA binding activity by incubating $5 \mu \mathrm{g}$ of protein with $\left[\gamma_{-}{ }^{33} \mathrm{P}\right] \mathrm{ATP}$ (PerkinElmer Life Science, Boston, MA) probes. DNA probes were generated by annealing complementary oligonucleotide sequences corresponding to the Bdnf promoter 4 NF- $\kappa$ B binding site ( $5^{\prime}$-tcgtGGACTCCCACCCACTTTCCcatt- $\left.3^{\prime}\right)$, the CRE (5'-agagattgcCTgACGTCAgagagctag-3'), or the intervening sequence (IS) (5'-CGTGGAGCCCTCTCGTGGA-3'). Uppercase letters indicate $B d n f$ promoter 4 sequences. The competitor IS sequence with a mutated E-box site is shown with the altered bases underlined, 5'-CGTGGAGCCCTCTACTGGA- $3^{\prime}$. Probes were end-labeled with $\left[\gamma_{-}{ }^{33} \mathrm{P}\right]$ ATP using T4 polynucleotide kinase.

Supershift gel shift assays. A total of $2 \mu \mathrm{g} / \mathrm{ml}$ rabbit polyclonal antibody to NF- $\kappa$ B p50, NF- $\kappa$ B p 65 (Santa Cruz Biotechnology, Santa Cruz, CA), or BHLHB2 (DEC1, Stra13) (Turley et al., 2004) was incubated with each nuclear extract for $20 \mathrm{~min}$ before addition of radiolabeled probe and incubated for $30 \mathrm{~min}$ at room temperature. DNA-protein complexes were fractionated through non-denaturing $6 \%$ polyacrylamide gels in $0.5 \times$ TBE buffer. Gels were dried and bands visualized by autoradiography.

Protein blots and enzyme-linked immunoassay. Phosphorylated (activated) I- $\kappa \mathrm{B}-\alpha$ (Ser 32 ), total I- $\kappa \mathrm{B}-\alpha$, phosphorylated (activated) CREB (Ser 133), and total CREB (Cell Signaling, Beverly, MA) were detected in lysates from hippocampal neurons (day 8 in vitro). Cultured neurons were treated with a subtoxic concentration of NMDA $(50 \mu \mathrm{M})$ at various times at $37^{\circ} \mathrm{C}$ in a $95 \%$ air $/ 5 \% \mathrm{CO}_{2}$ humidified incubator. At the indicated time, the culture medium was removed and the cells washed twice with ice-cold Locke's buffer containing $154 \mathrm{~mm} \mathrm{NaCl}, 5.6 \mathrm{~mm} \mathrm{KCl}, 1 \mathrm{~mm}$ $\mathrm{MgCl}_{2}, 2.3 \mathrm{~mm} \mathrm{CaCl}_{2}, 5.6 \mathrm{~mm}$ [SCAP] D-glucose, $8.6 \mathrm{~mm}$ HEPES, $1 \mathrm{~mm}$ vanadate, $\mathrm{pH}$ 7.4. Neurons were disrupted in $200 \mu \mathrm{l}$ of lysis buffer [ $[1 \%$ Nonidet P-40, 20 mm Tris, pH 8.0, $137 \mathrm{~mm} \mathrm{NaCl}, 10 \%$ glycerol, $1 \mathrm{~mm}$ PMSF, and protease inhibitors $(0.15 \mathrm{U} / \mathrm{ml}$ aprotinin, $20 \mu \mathrm{M}$ leupeptin, 1 mM sodium vanadate) $]$ at $4^{\circ} \mathrm{C}$. After removal of cellular debris by centrifugation, the supernatant was collected and protein levels in the lysates were measured by the Bradford Coomassie Blue colorimetric assay (BioRad Laboratories) and equalized by dilution with lysis buffer. Samples were boiled in the presence of sample buffer (NuPAGE LDS sample buffer; Invitrogen) for $5 \mathrm{~min}$ before separation on $10 \%$ SDSpolyacrylamide gels, and proteins were transferred to nitrocellulose membranes $(0.22 \mu \mathrm{m}$; Schleicher and Schuell, Keene, NH). After blocking with $5 \%$ nonfat dry milk dissolved in Tris-buffered saline containing $0.2 \%$ Tween 20 (TBST) for $30 \mathrm{~min}$, the immobilized proteins were incubated overnight at $4^{\circ} \mathrm{C}$ with specific antibodies and developed using enhanced chemiluminescence reagent (Amersham Biosciences, Piscataway, NJ). The same blot was stripped and reincubated with CREB or NF- $\kappa \mathrm{B}$ antibodies. BDNF protein levels were determined by a quantitative two-site enzyme immunoassay (Promega, Madison, WI) as described previously (Marini et al. 1998).

Bdnf promoter 4 reporter constructs, transfection, and reporter gene assays. Rat genomic DNA was used for PCR to generate a $400 \mathrm{bp}$ amplicon for subsequent cloning into a reporter plasmid. Each amplification primer incorporated a $B g l I I$ restriction endonuclease cleavage site cloning into BglIIdigested pDsRed2.1 (Promega). The PCR primer sequences were as follows: forward, 5' -TCAGATCTCTTCTGTGTGCGTGAGT-3', and reverse, 5' GGAGATCTCTCCTGTTCTTCAGCAA- $3^{\prime}$. These primers encompass the region -293 to +117 described by Nakayama et al. (1994). Additional promoter 4 reporter plasmids were produced for performing luciferase assays by subcloning the $400 \mathrm{bp}$ insert into pGL4.10 (Promega). Selection and propagation of $B d n f$ promoter 4-containing reporter plasmids was performed using standard molecular techniques. Inserts were verified by sequencing. Deletions and other site-directed mutations were created with a
QuikChange Site-Directed Mutagenesis kit (Stratagene, La Jolla, CA) and the mutagenic PCR primers listed in supplemental Table 1 (available at www.jneurosci.org as supplemental material). Mutations were confirmed by sequence analysis. Hippocampal neurons in culture were maintained in 24well plates for $3 \mathrm{~d}$ and then cotransfected with a combination of pbdnfDsRed and GFP constructs at a ratio of 2:1 using Lipofectamine 2000 (Invitrogen). Twenty-four hours after transfection, cells were treated with various concentrations of NMDA; $36 \mathrm{~h}$ after treatment, ratios of RED/green fluorescence protein (GFP) were measured. Expression of DsRed by transfected neurons was monitored using an Olympus IX70 microscope (Olympus, Melville, NY) interfaced with a Hamamatsu ORCA-ER digital camera (Hamamatsu, Tokyo, Japan). Fluorescence intensity measurements were performed using Openlab software (Improvision, Lexington, MA) and normalized for transfection efficiency using GFP, as described by Jiang et al. (2005a). Luciferase assays were done using primary rat hippocampal neurons cotransfected with either an intact $B d n f$ promoter 4 reporter plasmid (pbdnf-GL4.10; firefly luciferase) or mutated promoter 4 variants of $\mathrm{p} b d n f-$ pGL4.10 plus pRL-SV40 (Renilla luciferase) constructs, using Lipofectamine 2000. To control for transfection efficiency, we cotransfected the pbdnfGL4.10 luciferase plasmids and pRL-SV40 plasmids using a mass ratio of 50:1 or 100:1: pbdnf-GL4.10/pRL-SV40 Renilla luciferase plasmid for cotransfection experiments or triple transfection experiments, respectively. Twenty-four hours after transfection, the neurons were treated with $50 \mu \mathrm{M}$ NMDA for $6 \mathrm{~h}$. The cells were harvested for the Dual-Luciferase Reporter Assay (Promega) using passive lysis buffer. The activities of both firefly luciferase and Renilla luciferase were quantified as relative light units (RLU). Each pbdnf-pGL4.10 construct was transfected in triplicate. As a control, background RLU were determined in transfected neurons using a pGL4.10 plasmid with an inverted $B d n f$ promoter 4 and subtracted from experimental values. The ratio of firefly RLU to Renilla RLU for each sample well was determined, and the values were normalized to the intact $b d n f$ promoter 4 insert.

Bhlhb2 expression plasmids. Epitope-tagged BHLHB2 (FLAGBHLHB2) and the in-frame acidic form of the basic domain mutant (FLAG-BHLHB2 acidic) have been described previously (St. Pierre et al., 2002). These cDNAs were previously referred to as FLAG-Stra13 and FLAG-Stra13 (acidic) because of their murine origin.

Chromatin immunoprecipitation assays. Rat hippocampal neuron cultures (E20; $8 \mathrm{DIV}, 5 \times 10^{7}$ cells per condition) were treated with $50 \mu \mathrm{M}$ NMDA for $40 \mathrm{~min}$ or treated with vehicle before performing the assay, using an EZ-Chip kit (Upstate, Charlottesville, VA). Pooled samples from four culture dishes were used. For chromatin immunoprecipitation (ChIP) using brain tissue samples, samples were processed as described by Tsankova et al. (2004) and then cross-linked. Using either neuronal cells in culture or brain tissue, protein bound to DNA was cross-linked by treating the cultures with $1 \%$ formaldehyde at room temperature, stopping the reaction $10 \mathrm{~min}$ later by the addition of $2.5 \mathrm{M}$ glycine to a final concentration of $125 \mathrm{~mm}$, followed by $5 \mathrm{~min}$ incubation at room temperature. Cells were washed with cold PBS containing a protease inhibitor mixture (Roche, Nutley, NJ). Cells were recovered by centrifugation at $700 \times g$ at $4^{\circ} \mathrm{C}$ for $10 \mathrm{~min}$. The cell pellet was suspended in $1 \mathrm{ml}$ of SDS lysis buffer containing $10 \mathrm{~mm}$ EDTA, $0.5 \mathrm{~mm}$ EGTA, and $10 \mathrm{~mm}$ Tris-Cl, $\mathrm{pH} 8.0$, with protease inhibitor mixture, and incubated at $4^{\circ} \mathrm{C}$ for $10 \mathrm{~min}$. The final pellets were resuspended in $2 \mathrm{ml}$ of $1 \mathrm{~mm}$ Na-EDTA, $0.5 \mathrm{~mm}$ $\mathrm{Na}-\mathrm{EGTA}$, and $10 \mathrm{~mm}$ Tris-Cl, $\mathrm{pH} 8.0$, with protease inhibitor mixture, and were sonicated using a Misonix (Farmingdale, NY) sonicator 3000, MicrotipTM 419, at a power setting of 8, 10 pulses, $12 \mathrm{~s}$ on, $2.5 \mathrm{~min}$ off, separated by cooling on ice. Samples were centrifuged at $13,000 \times g, 4^{\circ} \mathrm{C}$ for $10 \mathrm{~min}$ to remove insoluble material, and the supernatant containing DNA-protein complexes was collected. This treatment produced DNA fragments with an average size of $500 \mathrm{bp}$. DNA content was estimated by processing a small aliquot of the purified, chromatin-reversed cross-links by adding $\mathrm{NaCl}$ to a final concentration of $0.5 \mathrm{M}$ and heating at $65^{\circ} \mathrm{C}$ for $5 \mathrm{~h}$, and then recovering the DNA by ethanol precipitation. An aliquot of $1 / 50 \mathrm{vol}\left(200 \mu \mathrm{l}\right.$ of $10 \mathrm{ml}$ dilution) was removed and stored at $-20^{\circ} \mathrm{C}$ for later analysis as an input control.

The cell supernatant was precleared with salmon sperm DNA/protein A agarose, $50 \%$ slurry for $1 \mathrm{~h}$ at $4^{\circ} \mathrm{C}$ with agitation and was centrifuged, and the supernatant was collected. For immunoprecipitation, $12.5 \mu \mathrm{g}$ of 
affinity-purified polyclonal anti-CREB, anti-p 65 NF- $\kappa$ B, RNA polymerase II (RNA pol II), or $12.5 \mu \mathrm{g}$ of the anti-peptide BHLHB2 antibody were added and incubated on a rocking platform overnight at $4^{\circ} \mathrm{C}$. In determining BHLHB2 antibody specificity, immunoprecipitations using anti-acetylated histone $\mathrm{H} 3$ ( $\mathrm{AcH} 3$ ) antibody (Upstate), were performed as a positive control. As a negative control, nonimmune rabbit IgG (Upstate) or buffer-only conditions were used in place of specific antibodies. Immune complexes were precipitated by the addition of salmon sperm $\mathrm{DNA}$ /protein A agarose slurry for $1 \mathrm{~h}$ at $4^{\circ} \mathrm{C}$ and pelleted at $700 \times g$ for 1 $\mathrm{min}$. The pellets were washed five times $(1 \mathrm{ml}$ each) in a low-salt wash buffer, high-salt wash buffer, and $\mathrm{LiCl}$ wash buffer, and twice with TE buffer. Immune complexes were finally eluted in $100 \mu \mathrm{l}$ of $1 \%$ SDS and $100 \mathrm{~mm} \mathrm{NaHCO}_{3}$ and were incubated at room temperature for $15 \mathrm{~min}$. Protein-DNA cross-links were reversed by adding $8 \mu \mathrm{l}$ of $5 \mathrm{M} \mathrm{NaCl}$ and incubating at $65^{\circ} \mathrm{C}$ for $5 \mathrm{~min}$, and by treatment with $1 \mathrm{U}$ of RNase A and $20 \mu \mathrm{g}$ of proteinase $\mathrm{K}$ at $37^{\circ} \mathrm{C}$ for $1 \mathrm{~h}$, and the resulting DNA was purified using PCR purification columns (Qiagen, Valencia, CA).

Levels of BHLHB2, CREB, NF- $\kappa$ B, and RNA pol II occupancy at Bdnf promoter 4 were determined by measuring the amount of each specific protein associated with DNA by a semiquantitative assay and subsequently validated by a quantitative real-time PCR assay using a 7700 Sequence Detector (Applied Biosystems, Foster City, CA). For the semiquantitative assay, specific PCR primers used to amplify rat $B d n f$ promoter 4 were as follows: forward, $5^{\prime}$-CTAGGACTGGAAGTGGAAA-3', and reverse, $5^{\prime}$-ATTTCATGCTAGCTCGCCG-3'. Conditions for PCR were as follows: 1 cycle of $94^{\circ} \mathrm{C}, 5 \mathrm{~min} ; 40$ cycles of $94^{\circ} \mathrm{C}, 15 \mathrm{~s} ; 58^{\circ} \mathrm{C}, 20 \mathrm{~s}$; $72^{\circ} \mathrm{C}, 30 \mathrm{~s}$, followed by an extension at $72^{\circ} \mathrm{C}, 7 \mathrm{~min}$. PCR products were resolved on TBE polyacrylamide gels, and the band was visualized by ethidium bromide staining. For semiquantitative determination of mouse $B d n f$ promoter 4 occupancy, the following PCR primers were used: forward, 5'-AAAGCATGCAATGCCCT-3', and reverse, 5'GAGATTTCATGCTAGCTCGC-3'. Molecular size was determined using appropriate size standards (O’GeneRuler; Fermentas, Hanover, $\mathrm{MD})$. Input and immunoprecipitated DNA reactions were performed in triplicate. Relative quantification of the $B d n f$ promoter 4 template was determined by the $\Delta \mathrm{Ct}$ method as described previously (Lipsky et al., 2001 ) with the modification that the $\Delta$ Ct value was normalized to input for each condition. Fold differences were then determined by raising 2 to the $\Delta \mathrm{Ct}$ power. Each PCR was performed in triplicate, and repeated at least two independent times. Fold differences relative to control were expressed as mean \pm SEM. To ensure specificity, it was necessary to design the quantitative assay using sequences $54 \mathrm{bp} 3^{\prime}$ of the transcription start site defined by Nakayama et al. (1994). The sequences of the primers were as follows: forward, 5' -CTGCCTAGATCAAATGGAGCTTCT-3', and reverse, 5' GGAAATTGCATGGCGGAGGTAA-3'. The detection probe sequence was as follows: 5' -TGAAGGCGTGCGAGT-3'.

Quantitative real-time RT-PCR of Bdnf, Bhlhb2, and c-fos mRNAs. Hippocampi from Bhlhb2 mutant mice and littermate controls were collected, and mRNA was isolated using RNeasy reagent (Qiagen). The purified RNA was subjected to DNase digestion (Ambion, Austin, TX) before performing first strand cDNA synthesis (SuperScript III first-strand synthesis system; Invitrogen). Levels of specific mRNAs were determined using real-time fluorescence 5 '-nuclease (TaqMan) assays. The following primers were used for amplifying specific regions of cDNA for each mRNA: Bhlhb2 (mouse), forward, 5'-GCCCACATGTACCAAGTGTACAAGT-3', reverse $5^{\prime}$-TCGTTAATCCGGTCACGTCTCTT-3', and detection probe $5^{\prime}$ AGACAGCAAGGAAACT-3'; $B d n f$ exon 1 (mouse and rat), forward, 5' AAGCCGAACTTCTCACATGATGA-3', reverse 5' -TGCAACCGAAGTATGAAATAACCATAG-3', and MGB detection probe, 5'-AAAGCCACAATGTTCCAC-3'); Bdnf exon 4 (mouse and rat), forward, 5'CTGCCTAGATCAAATGGAGCTTCT-3', reverse 5'-GGAAATTGCATGGCGGAGGTAA-3', detection probe $5^{\prime}$-TGAAGGCGTGCGAG-3'). The $\mathrm{c}-$ fos gene expression assay was obtained from Applied Biosystems (mouse assay ID Mm00487425_m1, reference sequence NM_010234). The TaqMan assay using a fluorogenic detection probe to exon 4 was described previously (Lipsky et al., 2001). Levels of specific mRNA from hippocampal tissue were normalized to endogenous Gapdh mRNA levels (rodent Gapdh mRNA assay; Applied Biosystems). Fold differences of specific mRNAs relative to control were calculated by an algorithm that determines the thresh-

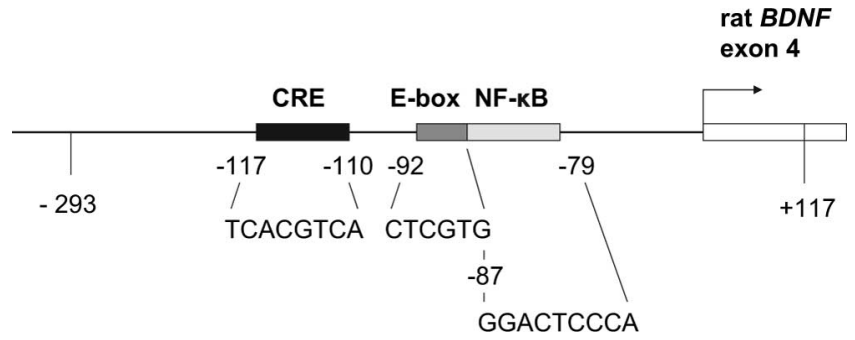

Figure 1. Schematic representation of rat $B d n f$ exon 4 promoter showing locations of regulatory elements evaluated in this study. Nucleotide positions relative to the transcription start site are according to Nakayama et al. (1994). The proximal E-box described here is shown (-92 to -87 ) flanked by the previously known (RE and NF- $\kappa$ B sites. Exon 4 is depicted as an open box with the transcription start site indicated by an arrow showing the direction of transcription.

old cycle $(\mathrm{Ct})$ when an increase in reporter fluorescence above a baseline signal is first detected during PCR. The sequence detection software generates a calibration curve of $\mathrm{Ct}$ versus amount of reference cDNA and then determines unknown amounts by interpolation. Real-time fluorescence detection was performed using a 7700 Sequence Detector (Applied Biosystems). RT-PCR assays, performed in triplicate, were repeated at least twice, unless stated.

Materials. Murine NIH3T3 fibroblasts were obtained from the American Type Culture Collection (Manassas, VA). NMDA, MK-801 (dizocilpine), and glutamate were obtained from Research Biochemicals (Natick, MA). Polyclonal BHLHB2 peptide antibody (residues 403-412; shares complete identity between rat and mouse sequences) has been described previously (Turley et al., 2004).

\section{Results}

\section{A 22 bp segment within the 5' flanking sequence represses} basal promoter activity

To identify nucleotide sequences within $B d n f$ promoter 4 that mediate activation-dependent responses, and to define the respective contribution of the different elements, a series of deletion mutations was created, and the effect of these deletions on NMDA-mediated DsRed reporter expression was determined in transfected hippocampal neurons. Four deletion mutations were created within the $40 \mathrm{bp}$ region (Fig. 1). One mutant retained the entire 5' flanking region of $B D N F$ exon 4 but deleted the CRE site ( $\Delta \mathrm{CRE},-117$ to -110 ) (Tao et al., 1998). Another deleted the NF- $\kappa$ B site $(\Delta \mathrm{NF}-\kappa \mathrm{B},-87$ to -79$)$ (Lipsky et al., 2001), whereas in the third mutant, the IS between the CRE and NF- $\kappa \mathrm{B}$ sites $(\Delta \mathrm{IS},-110$ to -87 ) was deleted. The fourth deletion removed the entire -117 to -79 region of promoter 4 . Neurons transfected with the intact promoter construct in the presence of increasing NMDA concentrations incrementally increased DsRed expression over the untreated control up to sixfold at the highest concentration of NMDA tested (200 $\mu \mathrm{M})$ (Fig. 2). However, deletion of CRE, NF- $\kappa \mathrm{B}$, or IS segments severely decreased responsiveness of the reporter gene in transfected neurons exposed to NMDA. Specifically, deletion of the CRE or NF- $\kappa$ B sites or the IS reduced NMDA-mediated responses to less than twofold compared with its matched untreated control at all concentrations of NMDA tested $(50-200 \mu \mathrm{M})$, although the responses by the NF- $\kappa$ B and IS mutations were significant (Fig. 2). Deletion of the entire -117 to -79 region of promoter 4 completely abolished responsiveness to NMDA (Fig. 2).

When the results were reanalyzed for basal expression, a different profile emerged. As shown in Figure 2, under basal conditions, reporter gene activity of the IS deletion mutant was increased more than fivefold relative the intact promoter, suggesting the presence of a repressor element within this $22 \mathrm{bp}$ 


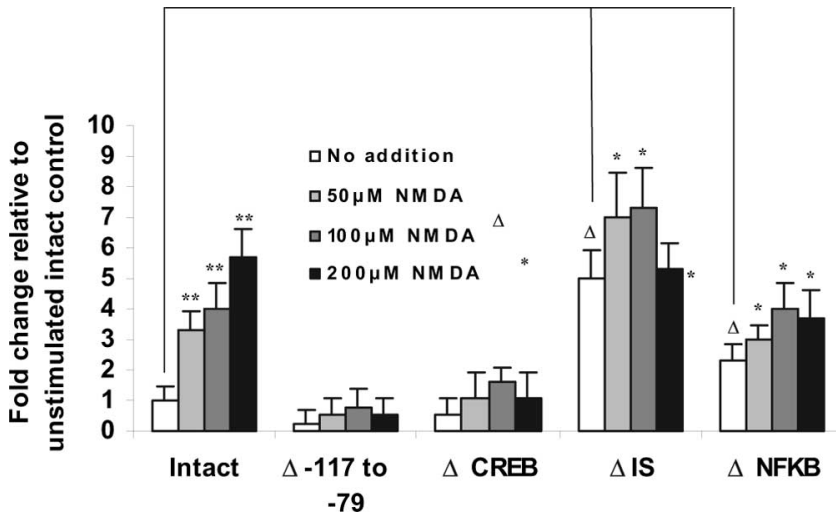

Figure 2. Basal and NMDA receptor-dependent changes in reporter gene activity for $B d n f$ promoter deletions. A reporter construct having an intact $B d n f$ promoter 4 , or constructs with a deletions of the CRE, or NF- $\kappa$ B binding sites, or the IS were cotransfected with a CMV-GFP plasmid into hippocampal neurons as described in Materials and Methods. Increasing concentrations of NMDA $(0-200 \mu \mathrm{m})$ were added to the cultures, and after $36 \mathrm{~h}$, ratios of RED/GFP protein were quantified. Neurons transfected with the intact promoter plasmid in the presence of increasing NMDA concentrations increased DsRed expression over the untreated control up to sixfold. Deletion of CRE, NF- $\kappa \mathrm{B}$, or IS segments decreased responsiveness of the reporter gene to NMDA. Deletion of the entire $-117 \mathrm{to}-79$ region of promoter 4 completely abolished responsiveness to NMDA. Under basal conditions, reporter gene activity of the IS deletion mutant increased more than fivefold relative to the intact promoter, suggesting the presence of a repressor element within the $I S$. Basal reporter gene levels for a construct lacking the entire promoter region ( -117 to -79 deletion), the CREB site, the $\mathrm{IS}$, or the NF- $\kappa B$ site were expressed relative to the intact promoter. Results are expressed as mean $\pm \operatorname{SEM}(n=6) .{ }^{* *} p<$ 0.01 versus intact promoter; ${ }^{*} p<0.05$ versus no addition; ${ }^{\circ} p<0.05$ basal (no addition) $\Delta \mathrm{IS}$ and $\Delta$ NF- $\kappa$ B versus intact promoter (no addition) by ANOVA and by Student's $t$ test.

segment. Deletion of the NF- $\kappa$ B site alone enhanced basal reporter activity in transfected hippocampal neurons by more than twofold relative to the intact promoter, indicating that this region may also contribute to silencing $B d n f$ exon 4 transcription. Deleting $n t-117$ to -79 abolished basal promoter 4 activity relative to the intact promoter. Deletion of the segment containing the CRE element did not significantly alter basal reporter activity in transfected neurons.

\section{NF- $\kappa$ B and CRE decoy DNAs block NMDA-mediated increases in $B d n f$ mRNA levels}

The promoter 4 region of human and rat $B d n f$ share $>95 \%$ sequence identity (Marini et al., 2004). The NF- $\kappa$ B site in Bdnf promoter 4 has complete sequence identity between rats and humans, whereas the CRE element in this region differs by a single nucleotide between the two species (Marini et al., 2004). Although rat $B d n f$ promoter 4 CRE (Tao et al., 1998) and NF- $\kappa B$ sites are functional in different neuronal populations (Lipsky et al., 2001), it is not known whether the NF- $\kappa$ B transcription factor binding site responds to NMDA receptor activation in hippocampal neurons. To approach this question, we performed two sets of experiments: (1) gel shift assays and (2) determination of steady-state levels of Bdnf exon 4-specific mRNA from NMDA-treated neurons that were pretreated with decoy DNAs with sequences derived from a consensus NF- $\kappa$ B binding site. In addition, we pretreated neurons with CRE decoy DNAs based on a consensus CRE sequence. Gel shift and plate binding assays were used to validate the specificity of the decoy DNAs used in subsequent experiments (supplemental material, available at www.jneurosci.org). Compared with untreated neurons, NMDA increased exon 4-specific Bdnf mRNA levels $>12$-fold (Fig. 3). Neurons pretreated with decoy DNAs for the NF- $\kappa \mathrm{B}$ or CRE attenuated the increase in $B d n f$ mRNA by twofold and threefold,

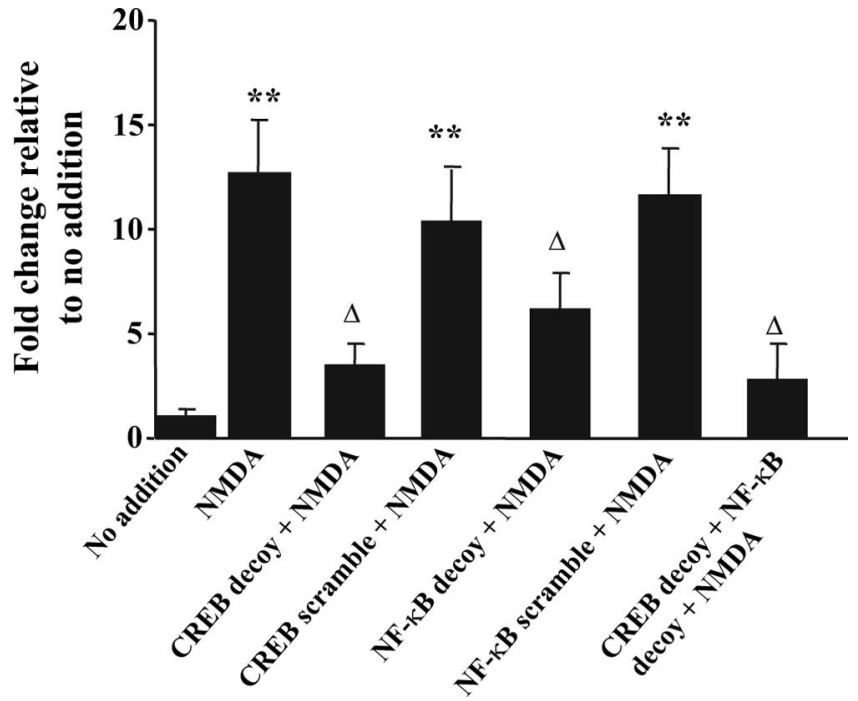

Figure 3. NF- $\kappa B$ and CREB are required to activate $B d n f$ promoter 4. Cultured rat hippocampal neurons were pretreated with a CREB decoy or scramble DNA $(112 \mu \mathrm{g})$ or the NF- $\kappa$ B decoy or scramble DNA $(112 \mu \mathrm{g})$ on day 7 in vitro followed by NMDA $(50 \mu \mathrm{m})$, for $6 \mathrm{~h}$, and total RNA prepared. Exon 4-specific Bdnf mRNA levels were determined by a $5^{\prime}$ nuclease assay and normalized to Gapdh mRNA levels. NMDA increased exon 4-specific $B d n f$ mRNA levels $>12$-fold. Neurons pretreated with NF- $\kappa B$ or CREB decoy DNA showed an attenuated response. Data are expressed as the mean $\pm S E M$ and plotted as relative fluorescence $(n=4) .{ }^{* *} p<0.01$ NMDA versus no addition, CREB scramble plus NMDA versus no addition, NF- $\kappa$ B scramble plus NMDA versus no addition; ${ }^{\Delta} p<0.05$ NMDA versus CREB decoy plus NMDA, NMDA versus NF- $\kappa B$ decoy plus NMDA, NMDA versus CREB decoy plus NF- $\kappa$ B decoy plus NMDA by ANOVA.

respectively (Fig. 3). These data indicate that NF- $\kappa \mathrm{B}$ and CREB each play important roles in NMDA-mediated activation of $B d n f$ promoter 4 by hippocampal neurons. Taken with the reporter gene results, these findings suggest that there may be differential regulation occurring at the NF- $\kappa \mathrm{B}$ site under basal and activitydependent conditions. In contrast, the CRE site behaves strictly as a positive modulator of $B d n f$ promoter 4 activity, as expected.

\section{Identification of a class B E-box element within the $22 \mathrm{bp}$ IS segment}

Because the previous deletion analysis indicated that sequences within the 22 bp IS could be involved in suppressing basal promoter 4 expression, we compared its sequence with that of known regulatory elements. We discovered a hexanucleotide sequence at position -92 to $-87\left(5^{\prime}\right.$-CTCGTG-3') (Fig. 1) that closely matched the consensus sequence for a class $\mathrm{B}$ E-box response element (5'-CACGTG-3') (St Pierre et al., 2002). Transcription factors of the bHLH family bind DNA through their basic domains after forming dimers (either homodimers or heterodimers). To test the hypothesis that the E-box-like element was responsible for repressing reporter gene activity, we generated another $B d n f$ promoter construct in which the E-box was disrupted, changing the sequence from $5^{\prime}$-CTCGTG- $3^{\prime}$ to $5^{\prime}$ CTACTG- $3^{\prime}$. This construct was transfected into hippocampal neurons, and basal reporter gene activity was measured. The activity of the mutant promoter (E-box mutant) was compared with that from neurons transfected with constructs having either an intact $B d n f$ promoter (IS intact) or having the IS deletion ( $\Delta \mathrm{IS}$, -110 to -87 ). The construct having the mutated E-box element showed a pattern of enhanced DsRed reporter gene activity similar to the IS deletion mutant. The deletion mutant and the dinucleotide mutant had threefold higher activity than the construct 


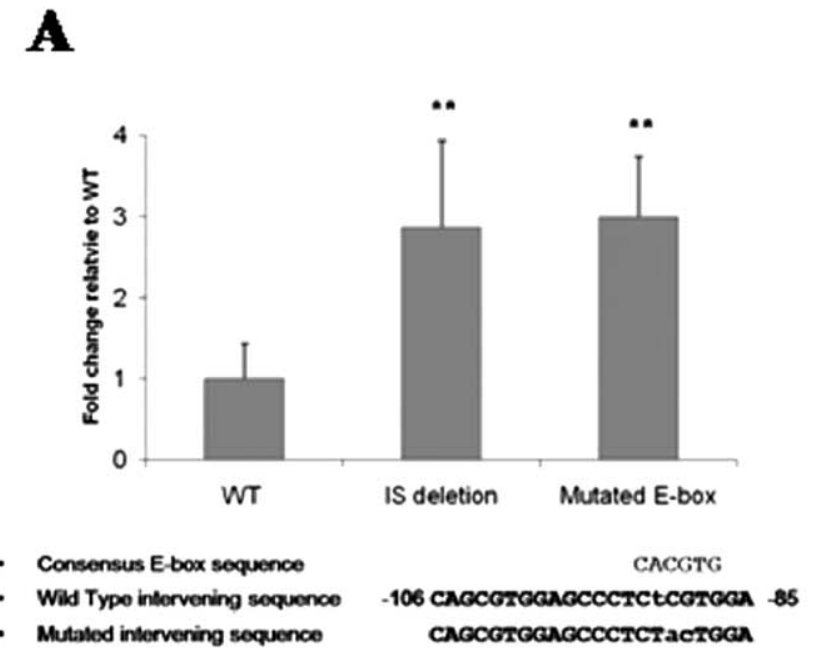

B

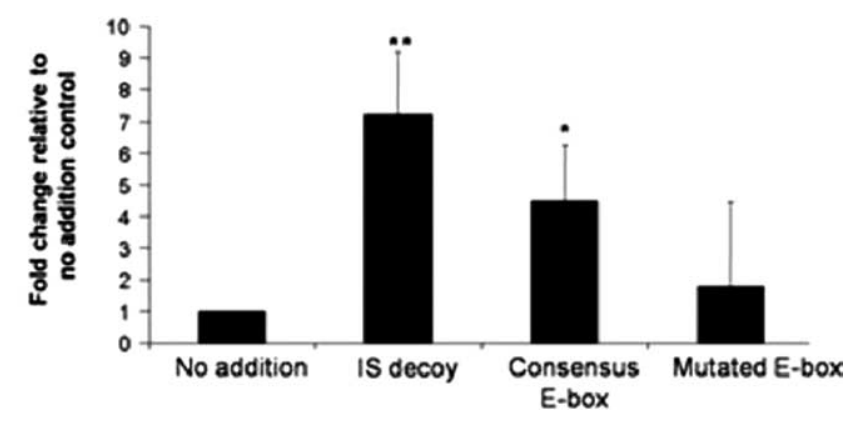

Figure 4. Proximal E-box sequence in Bdnf promoter 4 functions as a transcriptional suppressor. A pDsRed Bdnf promoter 4 reporter plasmid having a mutated proximal E-box element was constructed by site-directed mutagenesis (see Materials and Methods). Positions of the mutated bases are shown in lowercase letters $(\boldsymbol{A})$. Differences in pDsRed expression by transfected hippocampal neurons with Bdnf reporter promoter 4 constructs deleted for either the IS region or having a mutated E-box element. Expression was relative to the intact promoter (WT). The deletion mutant and the dinucleotide mutant had threefold higher activity than the construct with the intact $B d n f$ promoter. Experiments were performed five times in triplicate wells and fluorescence is expressed as mean $\pm \operatorname{SEM}(n=15)$. ${ }^{* *} p<0.01$ versus wild-type promoter $(\boldsymbol{A})$. In a second series of experiments, double-stranded decoy DNAs composed of the IS region $(-110$ to -87$)$, a consensus E-box, or a mutated E-box were used to transfect hippocampal neurons in culture for $24 \mathrm{~h}$ followed by determination of Bdnf exon 4-specific mRNA levels. Expression was determined by relative fluorescence relative to untreated control neurons, normalized for transfection efficiency. Compared with untreated neurons, the IS or consensus E-box decoy DNAs increased basal expression sevenfold and fourfold, respectively. The mutated E-box decoy showed no significant change relative to the no addition control neurons (mean \pm SEM; $n=12$ ). ${ }^{* *} p<0.01$ IS decoy versus no addition; ${ }^{*} p<0.05$ consensus E-box versus no $\operatorname{addition}(\boldsymbol{B})$.

with the intact $B d n f$ promoter (Fig. $4 A$ ), indicating that the E-box-like element was critical for repressing basal $B d n f$ expression in hippocampal neurons. To determine the effect of each sequence on $B d n f$ promoter 4 expression, double-stranded decoy DNAs were prepared containing a consensus E-box, the IS, or a mutated IS. Each double-stranded decoy DNA was transfected into cultured hippocampal neurons for $24 \mathrm{~h}$, and basal exon 4-specific $B d n f$ mRNA levels were quantified. Compared with untreated neurons, $B d n f$ expression was increased eightfold and fivefold in IS and consensus E-box decoy transfected cultures, respectively. In contrast, mutant E-box decoy DNA transfected cells showed no change in Bdnf expression (Fig. $4 B$ ).

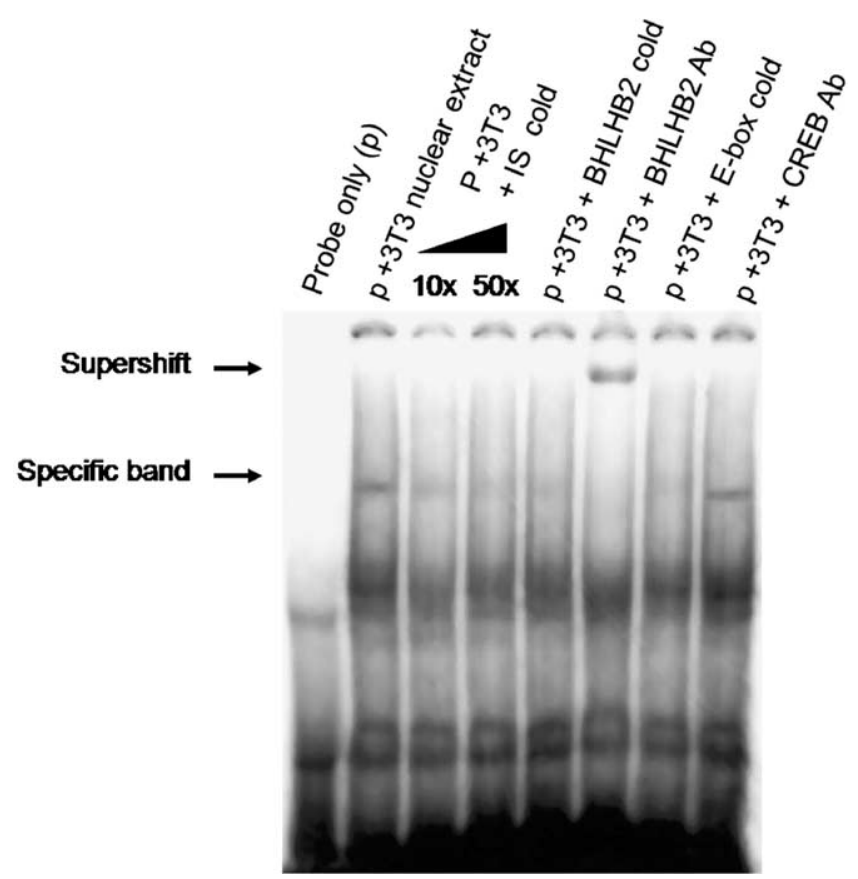

Figure 5. BHLHB2 is part of a protein-DNA complex associated with the proximal E-box element of Bdnf promoter 4. Autoradiograph showing a specific band indicative of a DNAprotein binding complex in NIH3T3 cell nuclear extracts to a ${ }^{33}$ P-labeled double-stranded DNA probe based on the $22 \mathrm{bp}$ rat $B d n f$ promoter $4 \mathrm{IS}$ region $(-110$ to -87$)$. Addition of unlabeled competitor DNA caused the binding activity to disappear in a concentration-dependent manner. Other consensus E-box containing competitor DNAs were also effective in eliminating the specific band. When a polyclonal BHLHB2 peptide antibody was incubated with the DNAprotein complex, the migration of the specific band was further retarded (shown by the arrow labeled "supershift"). No supershift was observed when the DNA-protein complex was incubated with a CREB-specific antibody.

\section{BHLHB2 is part of a protein complex that binds the $B d n f$} promoter 4 IS

By gel shift assay, a DNA-binding activity specific to the $22 \mathrm{bp}$ rat $B d n f$ promoter 4 IS target sequence was observed using nuclear extracts produced from serum-deprived NIH3T3 cells (see Materials and Methods). The DNA-binding activity was blocked by a 50 -fold molar excess of unlabeled (cold) IS probe (Fig. 5). In addition, a competitor DNA incorporating a class B E-box element that is known to interact with BHLHB2 (5' -TCACGTGA$3^{\prime}$ ) (St Pierre et al., 2002) or a consensus class B E-box sequence (5'-CACGTG-3') also blocked DNA binding to the probe. When nuclear extracts were incubated with the BHLHB2 antibody (Turley et al., 2004), a slow migrating or "supershift" band was observed with a loss of the specific band, consistent with the production of protein-antibody-DNA complex (Fig. 5). In contrast, preincubation with a CREB antibody failed to produce a supershift band.

Constitutive expression of BHLHB2 silences $B d n f$ promoter 4 in NIH3T3 cells and primary hippocampal neurons

Most bHLH proteins act as either positive or negative regulators of transcription (Einarson and Chao, 1995; Chien et al., 1996). BHLHB2 is an immediate-early gene expressed by different cell types, including hippocampal neurons (Rossner et al. 1997), and acts as a transcriptional repressor through class B E-box elements (St Pierre et al., 2002). Therefore, constitutive expression of BHLHB2 could potentially repress $B d n f$ promoter 4-mediated transcription through its DNA-binding domain. To test this hypothesis, we cotransfected NIH3T3 cells with a mouse in-frame 
$\mathbf{A}$

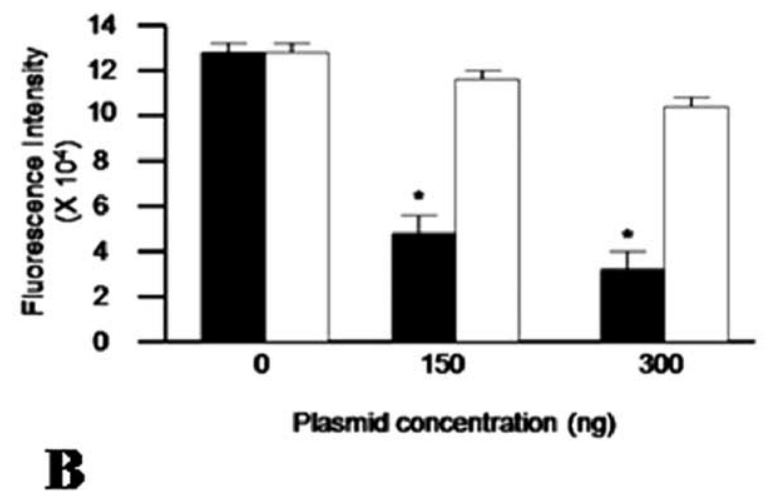

PCDNA3-FLAG-BHLHB2

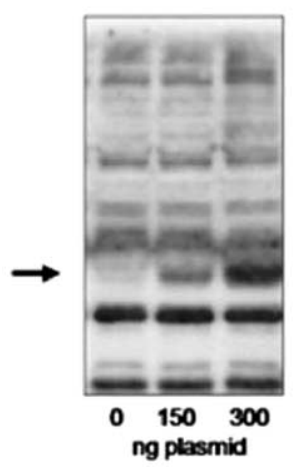

PCDNA3-FLAG-BHLHB2 Acidic

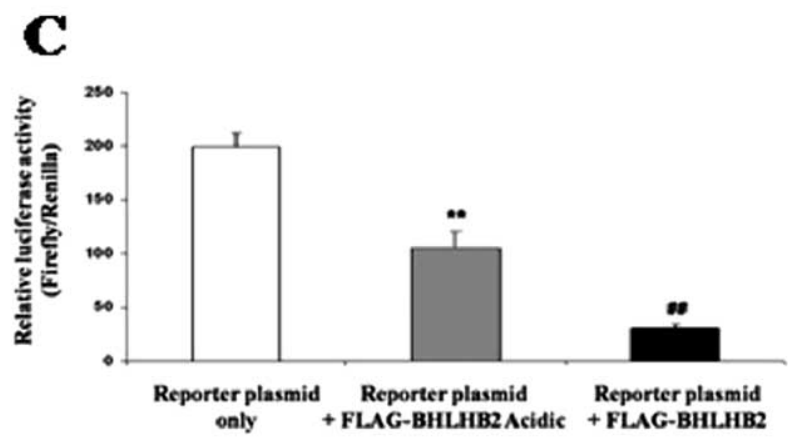

Figure 6. Constitutive expression of BHLHB2 represses rat $B d n f$ promoter 4-mediated expression by NIH3T3 cells and hippocampal neurons. DsRed expression was assayed in NIH3T3 cells cotransfected with a mouse in-frame amino-terminal FLAG epitope-tagged BHLHB2 expression plasmid ( $p C D N A 3-F L A G-B H L H B 2$ ) and the reporter plasmid. Reporter gene activity was repressed in a dose-dependent manner (black bars; $A$ ). ${ }^{*} p<0.01$, Student's $t$ test. To determine whether the repression was mediated by constitutive FLAG-BHLHB2 expression and not by other proteins, we performed cotransfection experiments with the $B$ dnf promoter 4 reporter plasmid and an expression plasmid encoding a mutant BHLHB2, in which the basic domain conferring DNA binding activity was replaced with an in-frame peptide rich in acidic residues (EEEDDEEE) (St. Pierre et al., 2002). Overexpression of the basic domain mutant (FLAG-BHLHB2 acidic) only slightly reduced reporter gene expression. As a control, a protein blot was performed using whole-cell lysates prepared from NIH3T3 cells cotransfected with pCDNA3-FLAGBHLHB2 and the reporter plasmid or a parallel culture cotransfected with pCDNA3-FLAGBHLHB2 acidic and the reporter plasmid. Proteins were fractioned on SDS-polyacrylamide gels, transferred to nylon membranes, and incubated with anti-FLAG antibody (1:5000) to show that the lack of reduced reporter gene activity in pcDNA-FLAG-BHLHB2 acidic transfected cells was not a result of reduced $B H L H B 2$ acidic expression $(\boldsymbol{B})$. The specific immunoreactive band representing each FLAG-BHLHB2 fusion protein is indicated by the arrow. Constitutive expression of BHLHB2 by hippocampal neurons cotransfected with a Bdnf-luciferase reporter gene plasmid also repressed transcription. Luciferase activity was measured in the Bdnf-luciferase reporter plasmid bdnf-pGL4.10. The effect on basal and NMDA receptor-mediated transcription was measured as relative luciferase level (ratio of firefly luciferase to Renilla luciferase) in transfected amino-terminal epitope-tagged BHLHB2 expression plasmid (pcDNA3-FLAG-BHLHB2) and the Bdnf promoter 4 reporter plasmid. We observed that NIH3T3 cells produced high levels of DsRed expression when cotransfected with the $B d n f$ promoter 4 reporter plasmid. Cotransfection with FLAG-BHLHB2 repressed the constitutively high level $B d n f$ promoter 4 activity observed in NIH3T3 cells in a dose-dependent manner, inhibiting reporter gene activity by $75 \%$ (300 ng of DNA) compared with control (Fig. 6A). To determine whether repression was mediated by constitutive FLAG-BHLHB2 expression and not by other proteins, we performed cotransfection experiments with the $B d n f$ promoter 4-DsRed reporter plasmid and mutant BHLHB2 expression plasmid, where the basic domain conferring DNA binding activity was replaced with an in-frame peptide rich in acidic residues (EEEDDEEE) (St. Pierre et al., 2002). This BHLHB2 mutant plasmid (FLAG-BHLHB2 acidic) failed to repress promoter 4 reporter gene expression at concentrations at which FLAG-BHLHB2 effectively repressed Bdnf promoter 4-DsRed expression, although a slight decrease in reporter gene activity was seen $(\sim 15 \%$ at $300 \mathrm{ng}$ of plasmid DNA) (Fig. $6 A)$. The observed differences in reporter gene expression were not caused by differences in levels of either FLAG-BHLHB2 or FLAG-BHLHB2 acidic produced by transfected NIH3T3 cells. Both epitopetagged proteins were highly expressed, as determined by protein blot in duplicate samples prepared from the transfected cells (Fig. $6 B$ ). To determine whether BHLHB2 could repress $B d n f$ promoter 4 activity in neurons, we cotransfected hippocampal neurons with FLAG-BHLHB2 or FLAG-BHLHB2-acidic plasmids and a luciferase reporter plasmid, pbdnf-GL4.10 (see Materials and Methods). Similar to the results obtained using NIH3T3 cells, neurons producing FLAG-BHLHB2 showed reduced luciferase activity compared with neurons transfected with the FLAGBHLHB2 acidic plasmid (Fig. 6C), confirming that BHLHB2 repressed $B d n f$ promoter 4 activity.

Mutation of the BHLHB2 repressor site does not compensate for loss of functional CRE or NF- $\kappa \mathrm{B}$ sites under basal conditions but normalizes promoter 4-dependent transcription in response to NMDA receptor activation Although our findings showed that the -117 to -79 region encompassing the CRE, E-box, and NF- $\kappa \mathrm{B}$ biding sites was critical for NMDA receptor-dependent transcription, we did not know whether loss of the functional BHLHB2 E-box binding site could counteract the loss of activation seen if the CRE or NF- $\kappa$ B sites were also eliminated. To address this question, we constructed reporter plasmids carrying double mutations within promoter 4 . Each plasmid had the same dinucleotide change in the BHLHB2 site sufficient to de-repress basal promoter activity (Fig. $4 \mathrm{~A}$ ) plus either trinucelotide or dinucleotide substitutions, eliminating the CRE or NF- $\kappa$ B p65 subunit binding sites (see Materials and Methods). In designing these experiments, we elected to use the pGL4.10 luciferase plasmid to increase the sensitivity of the reporter gene assay under basal conditions and after NMDA receptor activation. The mutated pbdnf-GL4.10 plasmids were then introduced into primary hippocampal neurons. Two important

$\longleftarrow$

primary hippocampal neurons cotransfected with the same FLAG-BHLHB2 and FLAG-BHLHB2 acidic constructs used previously ( $n=5$ per experimental group). Luciferase activity was suppressed in FLAG-BHLHB2 transfected neurons compared with the FLAG-BHLHB2 acidic control (C). ${ }^{* *} p<0.01$ for the $B d n f$ promoter 4 reporter plasmid/FLAG BHLHB2 acidic construct versus the $B d n f$ promoter 4 reporter plasmid alone. ${ }^{\#} p<0.01$ for $B d n f$ promoter 4 reporter plasmid/ FLAG BHLHB2 versus BDNF promoter 4 reporter plasmid/FLAG BHLHB2 acidic by Student's $t$ test. 

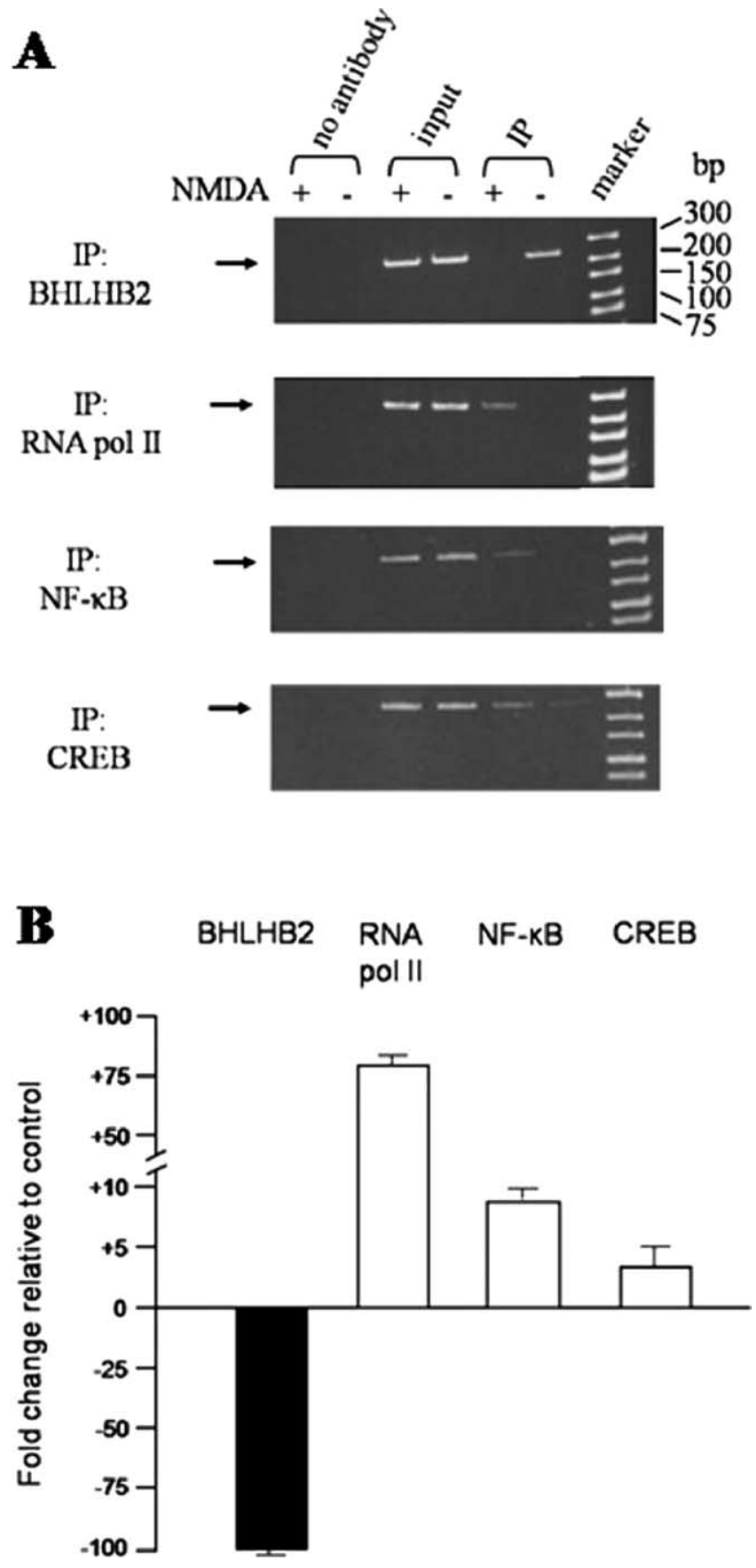

Figure 7. BHLHB2 occupancy of $B d n f$ promoter 4 is displaced by NF- $\kappa B, C R E B$, and RNA polymerase II after NMDA receptor activation. ChIP assays showing BHLHB2, NF- $\kappa B, C R E B$, and RNA polymerase II occupancy within the BDNF promoter 4 after 40 min NMDA receptor activation. Changes in promoter occupancy are shown by a semiquantitative $P C R$ assay $(\boldsymbol{A})$ (with the $275 \mathrm{bp} P C R$ product indicated by an arrow) and by a quantitative $P C R$ assay $(\boldsymbol{B})$. Values of promoter 4 occupancy shown in $\boldsymbol{B}$ are represented as mean \pm SEM of fold change over control $(n=6)$. Association of BHLHB2 with promoter 4 decreased, whereas RNA polymerase II, NF- $\kappa \mathrm{B}$, and CREB promoter occupancy increased after treatment of hippocampal neurons with $50 \mu \mathrm{m}$ NMDA after $40 \mathrm{~min}$. The representative semiquantitative $P C R$ assay also shows preimmunoprecipitated "inputs" from NMDA-treated and control neurons. A buffer-only "no antibody" condition was used as a negative control for the experiment shown in $\boldsymbol{A}$. Samples immunoprecipitated with nonimmune rabbit IgG produced similar results as "no antibody" controls.

findings were observed in these transfected neurons under basal conditions. First, cells carrying the mutated E-box only had significantly increased levels of luciferase activity compared with the intact promoter (supplemental Fig. 6, available at www. jneurosci.org as supplemental material), similar to the response observed for the same E-box mutation, but quantified by DsRed fluorescence (Fig. 4A). Second, by mutating either the CRE site or the NF- $\kappa \mathrm{B}$ site on a mutated E-box background, we observed significantly reduced basal luciferase activity, consistent with the loss of a positive regulatory element (supplemental Fig. 6, available at www.jneurosci.org as supplemental material). Thus, under basal conditions, the lack of an E-box binding site could not compensate for the loss of positive regulatory sites. In addition, these results showed that the assay was sufficiently sensitive to detect changes in promoter 4 activity reflected by the mutations. In a parallel set of experiments, transfected neurons were treated with $50 \mu \mathrm{M}$ NMDA. After $6 \mathrm{~h}$ of treatment, luciferase levels were determined. Cells transfected with pbdnf-GL4.10 incorporating the E-box mutation alone showed a twofold increase in luciferase activity relative to its matched untreated control. This response was significantly lower compared with neurons transfected with the intact pbdnf-GL4.10 plasmid (2.7-fold increase) (supplemental Fig. 6, available at www.jneurosci.org as supplemental material). When neurons having pbdnf-GL4.10 plasmids with mutations in both the E-box and CRE sites or the E-box and the p65 $\mathrm{NF}-\kappa \mathrm{B}$ sites were treated with NMDA and assayed for luciferase activity, each of the double mutants had significantly enhanced luciferase activity relative to the untreated control (2.6-fold for the E-box/NF- $\kappa$ B double mutant and 2.9-fold for the E-box/CRE double mutant) (supplemental Fig. 6, available at www.jneurosci.org as supplemental material). Together, these results suggested that eliminating the E-box site itself was insufficient to allow activity-dependent transcription from promoter 4 . Rather, mutating the CRE or NF- $\kappa \mathrm{B}$ sites on the mutant E-box background normalized activity-dependent response to that of the intact promoter (supplemental Fig. 6, available at www. jneurosci.org as supplemental material). These findings also suggest that loss of the BHLHB2 binding site, although enhancing basal transcription, may actually interfere with NMDA-receptor specific activation of the promoter, perhaps through competition by the CREB and NF- $\kappa \mathrm{B}$ factors for sites on promoter 4 .

\section{Reduced BHLHB2 occupancy of $B d n f$ promoter 4 after NMDA receptor activation}

To determine the role of endogenous BHLHB2 in the regulation of promoter 4 by NMDA receptors, we performed ChIP assays. Cross-linked chromatin from hippocampal neuron cultures treated with NMDA $(50 \mu \mathrm{M})$ or untreated neurons was sheared by sonication and subsequently incubated with antibodies specific to the p65 subunit of NF- $\kappa \mathrm{B}, \mathrm{CREB}, \mathrm{BHLHB} 2$ (DEC1) (Turley et al., 2004), or RNA pol II to immunoprecipitate proteins bound to the chromatin. Immunoprecipitated DNA was released from cross-linked proteins followed by semiquantitative PCR, performed using primers that amplified the Bdnf promoter 4 region flanking the E-box. Immunoprecipitation of chromatin with anti-BHLHB2 antibodies resulted in decreased amplification of $B d n f$ promoter 4 sequences in neurons treated with NMDA (Fig. 7A). In contrast, chromatin recovered with antip65, anti-CREB, or RNA polymerase II antibodies resulted in increased amplification products from $B d n f$ promoter 4 after neurons were treated with NMDA (Fig. 7A). To examine specificity of the BHLHB2 antibody, we performed another ChIP assay using cortical tissue from Bhlhb2 $-1-$ and Bhlhb2 $+/+$ mice (see Materials and Methods). Only the Bhlhb2 +/+ brain sample showed BHLHB2 bound to Bdnf promoter 4 , indicating the antibody did not recognize other proteins complexed with DNA (supplemental Fig. 7, available at www.jneurosci.org as supple- 
mental material). We next performed quantitative PCR, which showed that promoter occupancy by BHLHB2 of promoter 4 occurred only under basal conditions before treatment of neurons with NMDA (Fig. $7 B$ ). After NMDA receptor activation, a 3.5-fold increase in CREB binding and a 9-fold increase in NF- $\kappa \mathrm{B}$ binding occurred (Fig. $7 B$ ). These changes in transcription factor occupancy were consistent with induction of Bdnf exon 4 mRNA levels we observed previously after NMDA treatment (Jiang et al., 2005b). This idea was supported by the observation that, although NMDA-treated neurons had reduced BHLHB2 occupancy, they showed enhanced RNA pol II occupancy, consistent with transcriptional activation.

Quantitatively, these changes in promoter occupancy after NMDA receptor activation amounted to an 80 -fold increase in RNA polymerase II binding accompanied by a 90 -fold decrease in BHLHB2 binding (Fig. 7B).

\section{Basal levels of $B d n f$ exon 4 transcripts from Bhlhb2 KO mice are increased relative to $+/+$ littermates}

To determine the role(s) of BHLHB2 in controlling Bdnf promoter 4-specific transcription in brain, we generated Bhlhb2 KO mice in which the first four exons of Bhlhb2 encoding the entire bHLH domain responsible for both DNA-binding and dimerization were removed by Cre-mediated recombination. As expected, RT-PCR confirmed that no full-length Bhlhb2 messages were produced in the hippocampus of homozygous Bhlhb2 KO animals (supplemental Fig. 8, available at www.jneurosci.org as supplemental material). We also determined basal levels of exon 4-containing transcripts in hippocampus from littermates of each genotype group. Basal Bdnf exon 4 mRNA levels differed based on Bhlhb2 genotype. Homozygous Bhlhb2 knock-out mice showed a 1.6-fold increase in exon 4 mRNA levels compared with wild-type littermates $(p<0.01)$ (Fig. $8 A$ ). The levels of another activity-dependent $B d n f$ transcript, exon 1, in the same hippocampal samples were not significantly changed between genotypes, suggesting the difference in basal exon 4 mRNA levels was not the result of a general increase in gene expression (Fig. $8 \mathrm{~A}$ ). Using cortex samples from the same Bhlhb2 knock-out and $+/+$ animals, we also determined BDNF protein levels by ELISA (in picograms per milliliter; mean \pm SEM). BNDF levels were increased in Bhlhb2 $-/-$ mice $(37.1 \pm 8.12 \mathrm{pg} / \mathrm{ml})$ relative to Bhlhb2 $+/+$ mice $(25.0 \pm 6.04 \mathrm{pg} / \mathrm{ml})$, although the difference was not significant.

\section{Activity-dependent increase in $B d n f$ exon $4 \mathrm{mRNA}$ levels in hippocampus from Bhlhb2 KO mice compared with wild-type mice}

The ChIP findings suggested that BHLHB2-mediated repression of $B d n f$ exon 4 transcription was overcome through activation of NMDA receptors. We wanted to determine whether this derepression also occurred through an activation-dependent mechanism in vivo. It is know that $\mathrm{KA}$, a glutamate analog, activates $B d n f$ transcription from the Bdnf promoter 4 (Timmusk et al., 1993; Nakayama et al.,1994; Sathanoori et al., 2004; Aid et al., 2007). Therefore, to test for the role of Bhlhb2 in activitydependent Bdnf expression in vivo, Bhlhb2 knock-out and control mice, each received either a single intraperitoneal injection of KA (10 mg/kg) or a single PBS injection. Ninety minutes after injection, hippocampal tissue was recovered and total mRNA was isolated for real-time RT-PCR assays (see Materials and Methods). The $10 \mathrm{mg} / \mathrm{kg}$ dose was sufficient to induce $B d n f$ exon 4 mRNA levels 15 -fold after 90 min based on results obtained from hippocampal tissue prepared from $B h l h b 2+1+$ mice treated with
KA in preliminary experiments (supplemental Fig. 9, available at www.jneurosci.org as supplemental material). KA-treated Bhlhb2 - / - mice increased Bdnf exon 4 mRNA levels by 3-fold relative to wild-type mice, whereas Bhlhb2 $+/-$ mice increased exon 4 -containing transcripts by $>2.5$-fold relative to wild-type mice $(p<0.01)$ (Fig. $8 B$ ). Thus, Bhlhb2 mutant hippocampal neurons show enhanced basal and induced BDNF exon 4-containing transcript expression, as predicted. PBS-treated control mice had levels of exon 4 transcripts that were similar to basal levels of exon 4 transcripts from the different genotype groups (data not shown). To determine whether the genotypeassociated activity-dependent increase was specific, we measured $B d n f$ exon 1 and c-fos mRNA levels (KA is known to induce c-fos transcription) (Zhang et al., 2002) in the same samples. KA produced the expected increase in c-fos mRNA levels in hippocampus (18-fold after $90 \mathrm{~min}$ as determined in Bhlhb2 $+/+$ mice) (supplemental Fig. 9, available at www.jneurosci.org as supplemental material). $B d n f$ exon $1 \mathrm{mRNA}$ levels were also elevated in $B h l h b 2+1+$ mice relative to untreated mice (fivefold) (supplemental Fig. 9, available at www.jneurosci.org as supplemental material). However, no significant difference in c-fos or $B d n f$ exon 1 mRNA levels was observed in Bhlhb2 $+/-$ or $-/-$ mice relative to $B h l h b 2+/+$ littermates (Fig. $8 B$ ). Together, these results suggest that BHLHB2 negatively regulates $B d n f$ exon 4 transcription and that neuronal activity overcomes this repression.

\section{Bhlhb2 KO mice have increased susceptibility to kainate-induced seizures}

In performing the KA experiments, we noticed that seizure severity (staged as described in Materials and Methods) was greater for the Bhlhb2 - /- animals than for the either $+/+$ or $+/-$ genotype groups (Fig. $8 C)(p<0.02)$. Time of seizure initiation (from KA injection to achieve seizure) did not differ between genotype groups (data not shown). These results suggest an increase in neuronal excitability in Bhlhb2 -/- animals.

\section{Discussion}

\section{$B d n f$, a highly regulated activity-dependent gene}

The $B d n f$ gene has unique structural features. The human gene spans $>70 \mathrm{~kb}$ and is composed of at least seven $5^{\prime}$ exons that are differentially spliced to a single $3^{\prime}$ terminal exon (Liu et al., 2005). Each $5^{\prime}$ exon is transcribed from a unique promoter. This overall gene architecture is highly conserved in mammals. Initially, four promoters from $B d n f$ were characterized in the rat by Timmusk et al. (1993). More recently, five additional transcription start sites have been defined in this rodent (Aid et al., 2007). The well known promoter region BDNF flanking exon 4 [previously known as exon 3 (Timmusk et al., 1993; Aid et al., 2007)] is activated by membrane depolarization in cultured cortical and hippocampal neurons. Other activators of Bdnf exon 4-specific transcription have been described, including NMDA (Lipsky et al., 2001; Jiang et al., 2005b), kainate (Nakayama et al., 1994), and dopamine (Fang et al., 2003), with at least three transcription start sites mapped within an 80 bp region of DNA (Timmusk et al., 1993; Nakayama et al., 1994; Tao et al., 1998).

\section{NMDA receptors and BDNF activity-dependent transcription} NMDA receptors play a critical role in normal brain function. Activity-dependent transcription is thought to be a crucial mechanism by which neurons convert brief cellular changes into stable alterations in brain function. These transcriptional changes constitute a form of "molecular memory" (Dash et al., 1991; Hardingham et al., 2001) and are believed to contribute significantly to 

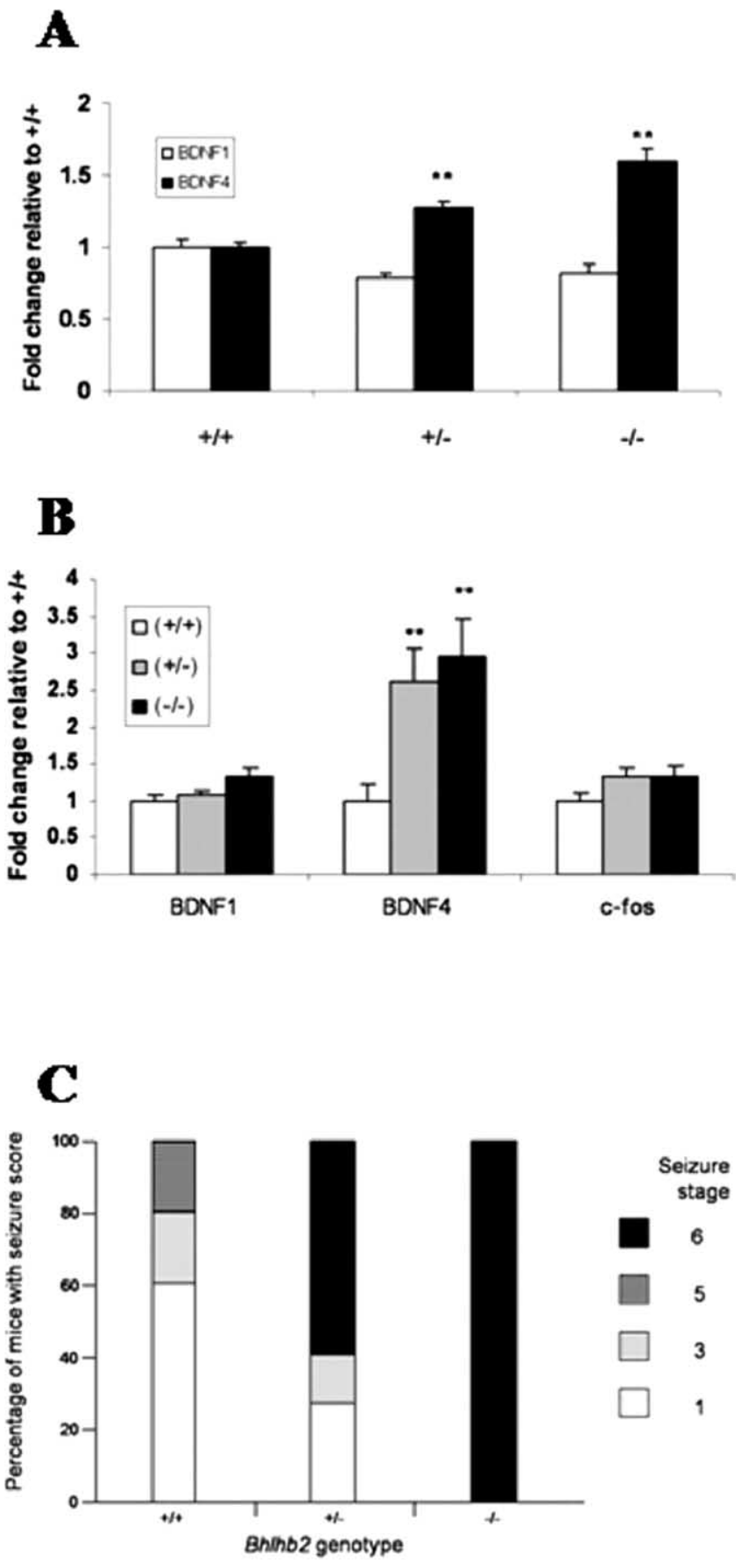

$F(2,14)=5.304 ; P=0.019$

Figure 8. Lack of $B h / h b 2$ increases basal and activation-dependent BDNF promoter 4 transcription in vivo. $A$, Levels of $B d n f$ promoter 1 and promoter 4 -driven $m R N A$ in the hippocampus from $B h / h b 2+/+, B h / h b 2+1-$, and $B h / h b 2-/-$ mice were determined by a real-time $P C R$ assay (see Materials and Methods). Mean expression values for each $B d n f$ transcript is shown after normalization to the average expression values of the Gapdh gene from each template. Data represent the means $\pm S D$ of five mice for $-/-$, eight for both $+/+$ and $+/-$ mice after calculation of ratios to expression levels in wild-type mice. The expression of promoter 4-driven Bdnf levels in the hippocampus of $+/-$ and $-/-$ mice were significantly higher than those specific mRNA levels in $+1+$ mice. ${ }^{* *} p<0.01$, Student's $t$ test. The promoter 1 driven BdnfmRNA levels showed no significant differences. $B, B$ Bhlhb2 $+1+,+1-$, and $-1-$ mice were injected intraperitoneally with $\mathrm{KA}$ in PBS $(10 \mathrm{mg} / \mathrm{kg})$. Total RNA was isolated from the hippocampus and amounts of $B d n f$ exon 4 and c-fos mRNA were determined by real-time $P C R$ and normalized to Gapdh mRNA levels. Data represent the expression means $\pm S D$ of three mice for Bhlhb2 - / - , five for Bhlhb2 +/ +, and four for Bhlhb2 $+/$ - mice relative to $+/+$ mice. Levels of promoter 4 driven $B d n f m R N A$ in the hippocampus of $B h / h b 2+/-$ and $-I-$ mice were higher than those in Bhlhb2 $+/+$ mice after 90 min treatment $10 \mathrm{mg} / \mathrm{kg}$ adaptive responses involved in plasticity. Changes in intracellular calcium $\left(\mathrm{Ca}^{2+}\right)$ brought about through one of these mechanisms, the activation of NMDA glutamate receptor subtypes, play an essential role in neuronal plasticity (Grover and Teyler, 1990; Bashir et al., 1991; Bliss and Collingridge, 1993; Katz and Shatz, 1996; Nagerl et al., 2004; Slutsky et al., 2004). NMDA receptors are required for other neuronal processes critical for brain function including neurogenesis (Natcher and McEwen, 2006), the proper balance between excitatory and inhibitory input (Liu et al., 2007) and in the aging brain (Magnusson, 2000).

Activation of NMDA receptors increases $B d n f$ mRNA levels in vivo and in vitro (Kokaia et al., 1993; Gwag and Springer, 1993; Favaron et al., 1993). Increases in NMDA receptor function mediate BDNF release to promote neuronal survival (Marini et al., 1998; Jiang et al., 2005b). BDNF enhances NMDA-mediated synaptic currents (Levine et al., 1998; Black, 1999) through an increase in NR1 (Suen et al., 1997) and NR2B (Lin et al., 1998) phosphorylation in the postsynaptic density. BDNF also increases AMPA-mediated currents through NMDA receptormediated mechanisms (Wu et al., 2004). The crucial relationship and interplay between the activation of NMDA receptors and BDNF release, which in turn amplifies NMDA receptor function to enhance critical excitatory physiological processes, provided the fundamental basis for studying this model.

In this study, we identified a previously undescribed regulatory element that is highly conserved between human, mouse, and rat $B d n f$ promoter 4 regions and acts as a transcriptional silencer under basal conditions. Our results, obtained using molecular, cellular, and genetic approaches, including gene knockout mice, support a role for BHLHB2 as a critical regulator of exon 4-specific $B d n f$ gene transcription. In addition, we characterized NMDA receptor-mediated transcriptional effects on promoter 4 in hippocampal neurons. In our experimental system, $\mathrm{Ca}^{2+}$-induced CREB phosphorylation on serine-133 by NMDAtreated hippocampal neurons was sustained up to $3 \mathrm{~h}$, confirming previous findings (Hardingham and Bading, 2003), and support a mechanism by which CREB is activated by synaptic NMDA receptors (Vanhoutte and Bading, 2003). We extended our previous findings that an NF- $\kappa \mathrm{B}$ site that responds to NMDA receptor activation in cultured rat cerebellar granule cells (Lipsky et al., 2001) is also responsive to NMDA treatment in hippocampal neuronal cultures. Nevertheless, the activation of both NF- $\kappa \mathrm{B}$ and CREB in this system is likely to have important biological significance in which NMDA receptor activation can effect changes in synaptic function by inducing $B d n f$ transcription and by enhancing its release into the extracellular milieu.

To determine the relative contribution of the CRE and NF- $\kappa \mathrm{B}$ elements, we generated three deletion mutations that retained the entire 5 ' flanking region of $B d n f$ exon 4 but deleted the CRE site, or the NF- $\kappa \mathrm{B}$ site, or the IS. Deleting either the CRE or NF- $\kappa \mathrm{B}$ sites incrementally decreased responsiveness of the reporter to different NMDA concentrations compared with the intact promoter. Deletion of the NF- $\kappa \mathrm{B}$ site enhanced basal promoter ac-

KA (BDNF4, ${ }^{* *} p<0.01$, Student's t test.). Promoter 1 driven Bdnf expression (BNDF1) and c-fos mRNA levels showed no significant differences between genotype groups. C, Susceptibility of Bh/hb2 mutant mice to kainate-induced seizures. Mice were injected intraperitoneally with KA $(10 \mathrm{mg} / \mathrm{kg}$ ). Mice were monitored and the extent of seizure activity was observed. Seizure severity (determined by forelimb clonus, partial rearing, rearing and falling) was scored according to stages as described in Materials and Methods. Seizure severity was greater for the Bhlhb2 $-/-$ animals than for the either $+/+$ or $+/-$ genotype groups; $p<0.02$ by ANOVA. 
tivity, suggesting that differential regulation occurs at this site. These differing results may be attributable to the fact that p50 homodimers can suppress transactivation by p50/p65 heterodimers acting on the same site (Guan et al., 2005). It is possible that p50 homodimers occupy the NF- $\kappa \mathrm{B}$ site under basal conditions, contributing to transcriptional repression. Additional analyses are needed to further define protein-DNA complexes at the NF- $\kappa \mathrm{B}$ site in vivo.

When the IS was deleted, basal reporter gene expression was significantly increased. Initially, this result was surprising because the 22 bp IS did not contain any predicted negative regulatory sequences. Subsequently, we discovered that the IS contained a sequence that closely resembled a class B E-box element with the core binding site sequence $5^{\prime}$-CTCGTG- $3^{\prime}$. Mutation of the E-box site alone de-repressed basal $B d n f$ transcription while decreasing the promoters responsiveness to NMDA receptor activation. Second mutations introduced into CRE or NF- $\kappa \mathrm{B}$ sites on the background of a nonfunctional E-box site normalized responsiveness to NMDA receptor activation to that of the intact promoter, supporting the idea that lack of a repressor binding site in promoter 4, although enhancing basal transcription, may actually interfere with NMDA-receptor specific activation of the promoter, perhaps through competition by the CREB and NF$\kappa \mathrm{B}$. Additional studies focused on examining the level of promoter 4 occupancy by CREB and NF- $\kappa$ B proteins under basal and activating conditions is required to determine whether competition for binding sites occurs because the reporter plasmid studies cannot duplicate in vivo chromatin structure.

Interestingly, activity-dependent changes in DNA methylation have been suggested to play an important role in regulating $B d n f$ transcription (Chen et al., 2003b; Martinowich et al., 2003). Of interest to this study, a CpG site corresponding to position -90 within this proximal E-box element was not methylated to a significant degree based on methylation patterns determined in cortical neurons (Chen et al., 2003b; Martinowich et al., 2003). Therefore, we thought it unlikely that methylation could regulate a potential site for protein-DNA interaction acting at the E-box. Because the double-stranded E-box decoy DNAs lacked any methyl-cytosine residues, it is unlikely that the observed increase in $B d n f$ exon 4 mRNA levels was a result of the binding of a factor that required a modified base. Although it appears unlikely that DNA methylation is responsible for the transcriptional repression of promoter 4 acting through the IS, the methylation status of $B d n f$ promoter 4 is not known in our hippocampal neuron cultures. Because BHLHB2 can also serve as a site for recruitment of histone deacetylase (HDAC) in repressing promoter 4, bHLH proteins may act in regions of hypomethylation in concert with CpG methylation sites distal to the -117 to -79 promoter 4 region to remodel chromatin, thereby repressing transcription. Future experiments focusing on methylation status of $B d n f$ promoter 4 and changes in HDAC and MeCP2 recruitment to the BHLHB2 site in vivo will help explain epigenetic changes at this site with neuronal activity. These approaches will be particularly useful in understanding the molecular mechanisms underlying increased basal and activity-dependent promoter 4 transcriptional activity in Bhlhb2 mutant mice (see below).

Other possible repressor binding sites exist within $B d n f$ promoter 4 . These include the proximal NF- $\kappa \mathrm{B}$ site $(-87$ to -79$)$ and downstream sequences $(-78$ to -69$)$ that may bind $\mathrm{p} 50$ homodimers and a distal upstream stimulatory factor (USF)/Ebox element ( -119 to -124$)$ (Chen et al., 2003a). In this regard, it is known that NF- $\kappa \mathrm{B}$ p50 homodimers and USF proteins repress transcription of genes having these sites in their $5^{\prime}$ flanking regions (Harris et al., 2000; Calomme et al., 2004; Grundstrom et al., 2004; Guan et al., 2005). In fact, ChIP experiments using chromatin prepared from hippocampal neurons in the absence of activation showed that $\mathrm{p} 50$ and USF1 are associated with $B d n f$ promoter 4 (X. Jiang and R. H. Lipsky, unpublished observation). The USF1 finding is entirely consistent with an in vivo interaction of USF1 and Bdnf promoter 4 seen in cortical neurons in the absence of stimulation (Chen et al., 2003a). Our reporter gene constructs with a deleted NF- $\kappa \mathrm{B}$ site had higher levels of activity under basal conditions, consistent with the idea that p50 homodimers acted on this site that was relieved after NMDA treatment. The NMDA-mediated induction of promoter 4 activity could be blocked by a specific decoy DNA (Fig. 3) that was based on the same sequence known to contain p65 subunits as part of the DNA-protein complex (supplemental Fig. 3, available at www.jneurosci.org as supplemental material), supporting the idea that differential binding occurs at the proximal NF- $\kappa \mathrm{B}$ site.

\section{A new role for $B h l h b 2$ in regulating $B d n f$ transcription}

In this report, we also showed that BHLHB2 plays a crucial role in regulating $B d n f$ promoter 4-mediated transcription in vivo. Hippocampi from mice lacking one or two copies of the Bhlhb2 gene have increased basal levels of $B d n f$ exon 4 mRNA compared with Bhlhb2 +/+ littermate control mice. These findings were supported by transfection experiments in cultured hippocampal neurons using decoy oligonucleotides, which also showed elevated basal and activity-dependent expression of $B d n f$ exon 4 mRNA. Support for an activation-dependent derepression of $B d n f$ promoter 4 was also evidenced by release of $\mathrm{BHLBH} 2$ from chromatin in hippocampal neurons maintained in culture and by the fact that Bhlhb2 KO mice show enhanced levels of $B d n f$ exon 4 transcripts when treated with KA, a known activator of $B d n f$ transcription (Timmusk et al., 1993; Nakayama et al., 1994). To provide additional evidence that BHLHB2 represses $B d n f$ promoter 4, we showed that constitutive expression of BHLHB2 repressed $B d n f$ promoter 4 -dependent transcription by transfected cells. However, promoter 4 activity was not completely abrogated when a DNA binding-deficient BHLHB2 protein was expressed, indicating that BHLHB2 may also repress $B d n f$ promoter 4 activity by a mechanism(s) that does not require direct interaction with DNA perhaps through sequestration of transcriptional activators. For example, BHLHB2 can disrupt USF-mediated transcription, via protein-protein interactions (Dhar and Taneja, 2001). It is also likely that BHLHB2 interacts with other bHLH proteins, such as its close relative Sharp-1 (DEC2/BHLHB3) (Garriga-Canut et al., 2001), to modulate transcription. Sharp-1 and BHLHB2 are both expressed in hippocampus (Rossner et al., 1997), although each protein shows different subregional localization. Interaction between these two bHLH protein family members is likely to have profound consequences for hippocampal function, because both genes are induced after glutamate stimulation in the adult rat (Rossner et al., 1997), an event associated with long-term adaptive changes. It should also be noted that, although our reporter gene findings are consistent with the negative effect of BHLHB2 on $B d n f$ transcription, there are limitations of cell culture-based experiments to account for transcriptional effects in vivo. As mentioned previously, reporter gene constructs cannot reproduce epigenetic events such as $\mathrm{CpG}$ methylation or nucleosome organization (Pringle et al., 2005). It was with these limitations in mind that generating the Bhlhb2 KO mice was justified.

Phenotypically, the Bhlhb2 KO mice were more susceptible to KA-induced seizures, suggesting that neuronal excitability is in- 
creased. It is well known that BDNF increases excitatory synaptic transmission in vitro in hippocampal slices (Binder et al., 2001). It is also known that $B d n f$ heterozygous knock-out mice require greater doses of KA to produce seizures (Barton and Shannon, 2005). Our finding that Bhlhb2 knock-out mice selectively increased $B d n f$ mRNA levels after activation with KA, suggests that $B d n f$ promoter 4 may be more responsive to activation. This may be attributable to the direct loss of BHLHB2 from a suppressor site on promoter 4 and possibly through remodeling of chromatin to a more "open" or transcriptionally responsive structure. Thus, BHLHB2, by controlling basal and activation-dependent $B D N F$ transcription, could potentially regulate BDNF levels, increasing excitation of limbic and other brain regions. A role for transcription factors in modulating neuronal excitability is known. Reduced CREB activity has been shown to reduce excitability of nucleus accumbens neurons (Dong et al., 2006), whereas loss of c-Fos leads to increased neuronal excitability (Zhang et al., 2002). Although it is plausible that increased BDNF expression has a role in increased seizure susceptibility in the Bhlhb2 knock-out mice, a critical next step will be to characterize precisely how BHLHB2 contributes to enhanced neuronal excitability and to define the mechanisms by which BHLHB2 is regulated in response to excitation. These future studies will likely provide important molecular information in defining the mechanisms by which excitatory amino acid receptors regulate neuronal excitability and adaptive responses.

\section{References}

Aid T, Kazantseva A, Piirsoo M, Palm K, Timmusk T (2007) Mouse and rat BDNF gene structure and expression revisited. J Neurosci Res 85:525-535.

Barton ME, Shannon E (2005) The seizure-related phenotype of brainderived neurotrophic factor knockdown mice. Neuroscience 136:563-569.

Bashir ZI, Alford S, Davies SN, Randall AD, Collingridge GL (1991) Longterm potentiation of NMDA receptor-mediated synaptic transmission in the hippocampus. Nature 349:156-158.

Binder DK, Croll SD, Gall CM, Scharfman HE (2001) BDNF and epilepsy: too much of a good thing? Trends Neurosci 24:47-53.

Black IB (1999) Trophic regulation of synaptic plasticity. J Neurobiol 41:108-118.

Bliss TV, Collingridge GL (1993) A synaptic model of memory: long-term potentiation in the hippocampus. Nature 36:31-39.

Calomme C, Dekoninck A, Nizet S, Adam E, Nguyen TL, Van Den Broeke A, Willems L, Kettmann R, Burny A, Van Lint C (2004) Overlapping CRE and $\mathrm{E}$ box motifs in the enhancer sequences of the bovine leukemia virus $5^{\prime}$ long terminal repeat are critical for basal and acetylation-dependent transcriptional activity of the viral promoter: implications for viral latency. J Virol 78:13848-13864.

Chao MV (2003) Neurotrophins and their receptors: a convergence point for many signaling pathways. Nat Rev Neurosci 4:299-309.

Chen WG, West AE, Tao X, Corfas G, Szentirmay MN, Sawadogo M, Vinson C, Greenberg ME (2003a) Upstream stimulatory factors are mediators of $\mathrm{Ca}^{2+}$-responsive transcription in neurons. J Neurosci 23:2572-2581.

Chen WG, Chang Q, Lin Y, Meissner A, West AE, Griffith EC, Jaenisch R, Greenberg ME (2003b) Derepression of BDNF transcription involves calcium-dependent phosphorylation of MeCP2. Science 302:885-889.

Cheng B, Furukawa K, O'Keefe JA, Goodman Y, Kihiko M, Fabian T, Mattson MP (1995) Basic fibroblast growth factor selectively increases AMPAreceptor subunit GluR1 protein level and differentially modulates $\mathrm{Ca}^{2+}$ responses to AMPA and NMDA in hippocampal neurons. J Neurochem 65:2525-2536.

Chien C, Hsiao C-D, Jan LY, Jan YN (1996) Neuronal type information encoded in the basic helix-loop-helix domain of proneuronal genes. Proc Natl Acad Sci USA 93:13239-13244.

Dash PK, Karl KA, Colicos MA, Prywes R, Kandel ER (1991) cAMP response element-binding protein is activated by $\mathrm{Ca}^{2+} /$ calmodulin- as well as cAMP-dependent protein kinase. Proc Natl Acad Sci USA 88:5061-5065.
Dhar M, Taneja R (2001) Cross-regulatory interaction between Stra13 and USF results in functional antagonism. Oncogene 20:4750-4756.

Dong Y, Green T, Saal D, Marie H, Neve R, Nestler EJ, Malenka RC (2006) CREB modulates excitability of nucleus accumbens neurons. Nat Neurosci 9:475-477.

Einarson MB, Chao MV (1995) Regulation of Id 1 and its association with basic helix-loop-helix proteins during nerve growth factor-induced differentiation of PC12 cells. Mol Cell Biol 15:4175-4183.

Ernfors P, Wetmore C, Olson L, Persson H (1990) Identification of cells in rat brain and peripheral tissues expressing mRNA for members of the nerve growth factor family. Neuron 5:511-526.

Fang H, Chartier J, Sodja C, Desbois A, Ribecco-Lutkiewicz M, Walker PR, Sikorska M (2003) Transcriptional activation of the human brainderived neurotrophic factor gene promoter III by dopamine signaling in NT2/N neurons. J Biol Chem 278:26401-26409.

Favaron M, Manev RM, Rimland JM, Candeo P, Beccaro M, Manev H (1993) NMDA-stimulated expression of BDNF mRNA in cultured cerebellar granule neurones. NeuroReport 4:1171-1174.

Frank DA, Greenberg ME (1994) CREB: a mediator of long-term memory from mollusks to mammals. Cell 79:5-8.

Freudenthal R, Romano A (2000) Participation of Rel/NF-kappaB transcription factors in long-term memory in the crab Chasmagnathus. Brain Res 855:274-281.

Freudenthal R, Romano A, Routtenberg A (2004) Transcription factor $\mathrm{NF}-\kappa \mathrm{B}$ activation after in vivo perforant path LTP in mouse hippocampus. Hippocampus 14:677-683.

Fu W, Lu C, Mattson MP (2002) Telomerase mediates the cell survivalpromoting actions of brain-derived neurotrophic factor and secreted amyloid precursor protein in developing hippocampal neurons. J Neurosci 22:10710-10719.

Garriga-Canut M, Roopra A, Buckley NJ (2001) The basic helix-loop-helix protein, sharp-1, represses transcription by a histone deacetylasedependent and histone deacetylase-independent mechanism. J Biol Chem 276:14821-14828.

Ghosh A, Carnahan J, Greenberg ME (1994) Requirement for BDNF in activity-dependent survival of cortical neurons. Science 263:1618-1623.

Grover LM, Teyler TJ (1990) Two components of long-term potentiation induced by different patterns of afferent activation. Nature 347:477-479.

Grundstrom S, Anderson P, Scheipers P, Sundstedt A (2004) Bcl-3 and NFkappaB p50-p50 homodimers act as transcriptional repressors in tolerant CD4+ T cells. J Biol Chem 279:8460-8468.

Guan H, Hou S, Ricciardi RP (2005) DNA binding of repressor NF-kappa B p50/p50 depends on phosphorylation of Ser337 by PKAc. J Biol Chem 280:9957-9962.

Gwag BJ, Springer JE (1993) Activation of NMDA receptors increases brainderived neurotrophic factor (BDNF) mRNA expression in the hippocampal formation. NeuroReport 18:125-128.

Hardingham GE, Bading H (2003) The Yin and Yang of NMDA receptor signaling. Trends Neurosci 26:81-89.

Hardingham GE, Arnold FJ, Bading H (2001) Nuclear calcium signaling controls CREB-mediated gene expression triggered by synaptic activity. Nat Neurosci 4:261-267.

Harris VK, Coticchia CM, List HJ, Wellstein A, Riegel AT (2000) Mitogeninduced expression of the fibroblast growth factor-binding protein is transcriptionally repressed through a non-canonical E-box element. J Biol Chem 275:28539-28548.

Jiang X, Xu K, Hoberman J, Tian F, Marko AJ, Waheed JF, Harris CR, Marini AM, Enoch M-A, Lipsky RH (2005a) BDNF variation and mood disorders: a novel functional promoter polymorphism and Val66Met are associated with anxiety but have opposing effects. Neuropsychopharmacology 30:1353-1361.

Jiang X, Tian F, Mearow K, Okagaki P, Lipsky RH, Marini AM (2005b) The excitoprotective effect of $N$-methyl-D-aspartate is mediated by a BDNF autocrine loop in cultured hippocampal neurons. J Neurochem 94:713-722.

Kafitz KW, Rose CR, Thoenen H, Konnerth A (1999) Neurotrophin-evoked rapid excitation through TrkB receptors. Nature 401:918-921.

Katz LC, Shatz CJ (1996) Synaptic activity and the construction of cortical circuits. Science 274:1133-1138.

Kokaia Z, Gido G, Ringstedt T, Bengzon J, Kokaia M, Siesjo BK, Persson H, Lindvall O (1993) Rapid increase of BDNF mRNA levels in cortical neurons following spreading depression: regulation by glutamatergic mech- 
anisms independent of seizure activity. Brain Res Mol Brain Res 19:277-286.

Levine ES, Crozier RA, Black IB, Plummer MR (1998) Brain-derived neurotrophic factor modulates hippocampal synaptic transmission by increasing $N$-methyl-D-aspartic acid receptor activity. Proc Natl Acad Sci USA 95:10235-10239.

Lin SY, Wu K, Levine ES, Mount HT, Suen PC, Black IB (1998) BDNF acutely increases tyrosine phosphorylation of the NMDA receptor subunit $2 \mathrm{~B}$ in cortical and hippocampal postsynaptic densities. Brain Res Mol Brain Res 55:20-27.

Lipsky RH, Xu K, Zhu D, Kelly C, Terhakopian A, Novelli A, Marini AM (2001) Nuclear factor kappaB is a critical determinant in N-methyl-Daspartate receptor-mediated neuroprotection. J Neurochem 78:254-264.

Liu H, Cao Y, Basbaum AI, Mazarati AM, Sankar R, Wasterlain CG (1999) Resistance to excitotoxin-induced seizures and neuronal death in mice lacking the preprotachykinin A gene. Proc Natl Acad Sci USA 96:12096-12101.

Liu P, Jenkins NA, Copeland NG (2003) A highly efficient recombineeringbased method for generating conditional knockout mutations. Genome Res 13:476-484.

Liu QR, Walther D, Drgon T, Polesskaya O, Lesnick TG, Strain KJ, de Andrade M, Bower JH, Maraganore DM, Uhl GR (2005) Human brain derived neurotrophic factor (BDNF) genes, splicing patterns, and assessments of associations with substance abuse and Parkinson's disease. Am J Med Genet B Neuropsychiatr Genet 134:93-103.

Liu Y, Zhang LI, Tao HW (2007) Heterosynaptic scaling of developing GABAergic synapses: dependence on glutamatergic input and developmental stage. J Neurosci 27:5301-5312.

Lu B, Figurov A (1997) Role of neurotrophins in synapse development and plasticity. Rev Neurosci 8:1-12.

Magnusson KR (2000) Declines in mRNA expression of different subunits may account for differential effects of aging on agonist and antagonist binding to the NMDA receptor. J Neurosci 20:1666-1674.

Marini AM, Rabin SJ, Lipsky RH, Mocchetti I (1998) Activity-dependent release of brain-derived neurotrophic factor underlies the neuroprotective effect of $N$-methyl-D-aspartate. J Biol Chem 273:29394-29399.

Marini AM, Jiang X, Wu X, Tian F, Zhu D, Okagaki P, Lipsky RH (2004) Role of brain-derived neurotrophic factor and NF-kappaB in neuronal plasticity and survival: from genes to phenotype. Restor Neurol Neurosci 22:121-130.

Martinowich K, Hattori D, Wu H, Fouse S, He F, Hu Y, Fan G, Sun YE (2003) DNA methylation-related chromatin remodeling in activity-dependent BDNF gene regulation. Science 302:890-893.

Mattson MP, Culmsee C, Yu Z, Camandola S (2000) Roles of nuclear factor kappaB in neuronal survival and plasticity. J Neurochem 74:443-456.

Meberg PJ, Kinney WR, Valcourt EG, Routtenberg A (1996) Gene expression of the transcription factor NF-kappa B in hippocampus: regulation by synaptic activity. Brain Res Mol Brain Res 38:179-190.

Meffert MK, Chang JM, Wiltgen BJ, Fanselow MS, Baltimore D (2003) NFkappa B functions in synaptic signaling and behavior. Nat Neurosci 6:1072-1078

Nagerl UV, Eberhorn N, Cambridge SB, Bonhoeffer T (2004) Bidirectional activity-dependent morphological plasticity in hippocampal neurons. Neuron 44:759-767.

Nakayama M, Gahara Y, Kitamura T, Ohara O (1994) Distinctive four promoters collectively direct expression of brain-derived neurotrophic factor gene. Brain Res Mol Brain Res 21:206-218.

Natcher J, McEwen BS (2006) The role of $N$-methyl-D-asparate receptors in neurogenesis. Hippocampus 16:267-270.

Perry T, Lahiri DK, Sambamurti K, Chen D, Mattson MP, Egan JM, Greig NH (2003) Glucagon-like peptide-1 decreases endogenous amyloid-beta peptide (Abeta) levels and protects hippocampal neurons from death induced by Abeta and iron. J Neurosci Res 72:603-612.

Phillips HS, Hains JM, Laramee GR, Rosenthal A, Winslow JW (1990) Widespread expression of BDNF but not NT3 by target areas of basal forebrain cholinergic neurons. Science 250:290-294.
Pringle IA, Raman S, Sharp WW, Cheng SH, Hyde SC, Gill DR (2005) Detection of plasmid DNA vectors following gene transfer to the murine airways. Gene Ther 12:1206-1214.

Rossner MJ, Dorr J, Gass P, Schwab MH, Nave KA (1997) SHARPs: mammalian enhancer-of-split- and hairy-related proteins coupled to neuronal stimulation. Mol Cell Neurosci 10:460-475.

Sathanoori M, Dias BG, Nair AR, Banerjee SB, Tole S, Vaidya VA (2004) Differential regulation of multiple brain-derived neurotrophic factor transcripts in the postnatal and adult rat hippocampus during development, and in response to kainate administration. Brain Res Mol Brain Res 130:170-177.

Schwartz PM, Borghesani PR, Levy RL, Pomeroy SL, Segal RA (1997) Abnormal cerebellar development and foliation in $\mathrm{BDNF}-/-$ mice reveals a role for neurotrophins in CNS patterning. Neuron 19:269-281.

Slutsky I, Sadeghpour S, Li B, Liu G (2004) Enhancement of synaptic plasticity through chronically reduced $\mathrm{Ca}^{2+}$ flux during uncorrelated activity. Neuron 44:835-849.

St. Pierre B, Flock G, Zacksenhaus E, Egan SE (2002) Stra13 homodimers repress transcription through class B E-box elements. J Biol Chem 277:46544-46551.

Suen PC, Wu K, Levine ES, Mount HT, Xu JL, Lin SY, Black IB (1997) Brain-derived neurotrophic factor rapidly enhances phosphorylation of the postsynaptic $N$-methyl-D-aspartate receptor subunit 1 . Proc Natl Acad Sci USA 94:8191-8195.

Sun H, Taneja R (2000) Stra13 expression is associated with growth arrest and represses transcription through histone deacetylase (HDAC)dependent and HDAC-independent mechanisms. Proc Natl Acad Sci USA 97:4058-4063.

Sun H, Lu B, Li RQ, Flavell RA, Taneja R (2001) Defective T cell activation and autoimmune disorder in Stra13-deficient mice. Nat Immunol 2:10440-10447.

Tao X, Finkbeiner S, Arnold DB, Shaywitz AJ, Greenberg ME (1998) $\mathrm{Ca}^{2+}$ influx regulates BDNF transcription by a CREB family transcription factor-dependent mechanism. Neuron 20:709-726.

Thoenen H (1995) Neurotrophins and neuronal plasticity. Science 270:593-596.

Timmusk T, Palm K, Metsis M, Reintam T, Paalme V, Saarma M, Persson H (1993) Multiple promoters direct tissue-specific expression of the rat BDNF gene. Neuron 10:475-489.

Tsankova N, Kumar A, Nestler E (2004) Histone modifications at gene promoter regions in rat hippocampus after acute and chronic electroconvulsive seizures. J Neurosci 24:5603-5610.

Turley H, Wykoff CC, Troup S, Watson PH, Gatter KC, Harris AL (2004) The hypoxia-regulated transcription factor DEC1 (Stra13, BHLHB2) and its expression in human tissues and tumours. J Pathol 203:808-813.

Vajda FJ (2002) Neuroprotection and neurodegenerative disease. J Clin Neurosci 9:4-8.

Vanhoutte P, Bading H (2003) Opposing roles of synaptic and extrasynaptic NMDA receptors in neuronal calcium signalling and BDNF gene regulation. Curr Opin Neurobiol 13:366-371.

Wood MA, Kaplan MP, Park A, Blanchard EJ, Oliveira AM, Lombardi TL, Abel T (2005) Transgenic mice expressing a truncated form of CREBbinding protein (CBP) exhibit deficits in hippocampal synaptic plasticity and memory storage. Learn Mem 12:111-119.

Wu K, Len GW, McAuliffe G, Ma C, Tai JP, Xu F, Black IB (2004) Brainderived neurotrophic factor acutely enhances tyrosine phosphorylation of the AMPA receptor subunit GluR1 via NMDA receptor-dependent mechanisms. Brain Res Mol Brain Res 130:178-186.

Yan Q, Rosenfeld RD, Matheson CR, Hawkins N, Lopez OT, Bennett L, Welcher AA (1997) Expression of brain-derived neurotrophic factor in the adult rat central nervous system. Neuroscience 78:431-448.

Yin JC, Wallach JS, Del Vecchio M, Wilder EL, Zhou H, Quinn WG, Tully T (1994) Induction of a dominant negative CREB transgene specifically blocks long-term memory in Drosophila. Cell 79:49-58.

Zhang J, Zhang D, McQuade JS, Behbehani M, Tsien JZ, Xu M (2002) c-fos regulates neuronal excitability and survival. Nat Genet 30:416-420. 